Portland State University

PDXScholar

1989

\title{
Collective Bargaining for Educational Administrators: Oregon and Washington Principals' Perceptions of Working Conditions
}

Patricia Ann Boles

Portland State University

Follow this and additional works at: https://pdxscholar.library.pdx.edu/open_access_etds Let us know how access to this document benefits you.

Recommended Citation

Boles, Patricia Ann, "Collective Bargaining for Educational Administrators: Oregon and Washington Principals' Perceptions of Working Conditions" (1989). Dissertations and Theses. Paper 1369.

https://doi.org/10.15760/etd.1368

This Dissertation is brought to you for free and open access. It has been accepted for inclusion in Dissertations and Theses by an authorized administrator of PDXScholar. Please contact us if we can make this document more accessible: pdxscholar@pdx.edu. 
COLLECTIVE BARGAINING FOR EDUCATIONAL ADMINISTRATORS: OREGON AND WASHINGTON PRINCIPALS' PERCEPTIONS OF WORKING CONDITIONS

by

PATRICIA ANN BOLES

A dissertation submitted in partial fulfillment of the requirements for the degree of

DOCTOR OF EDUCATION in

EDUCATIONAL LEADERSHIP

Portland state University

1989 
TO THE OFFICE OF GRADUATE STUDIES:

The members of the committee approve the dissertation of Patricia Ann Boles presented April 19, 1989.

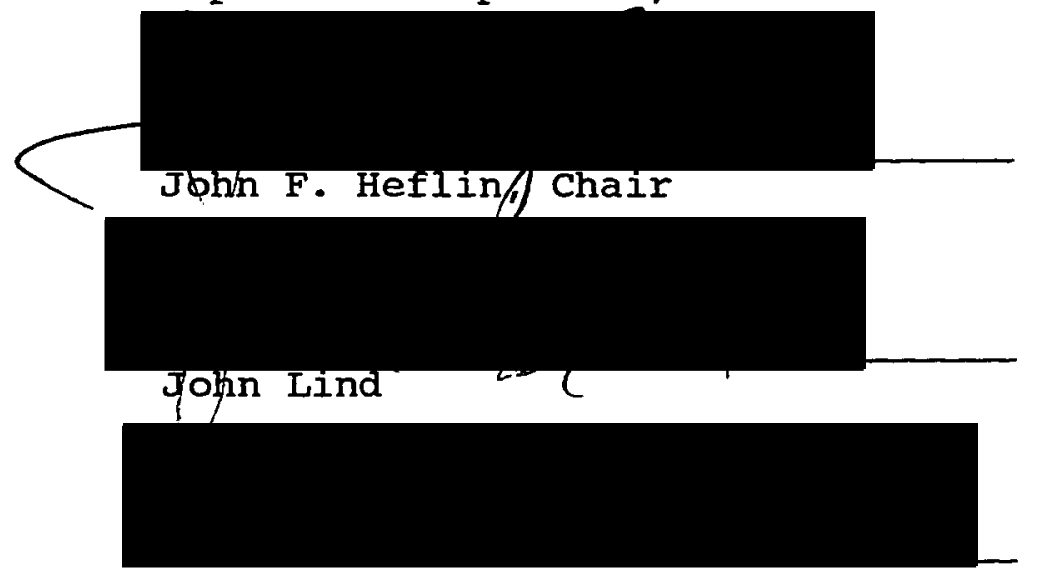

Kathleen Westbrook

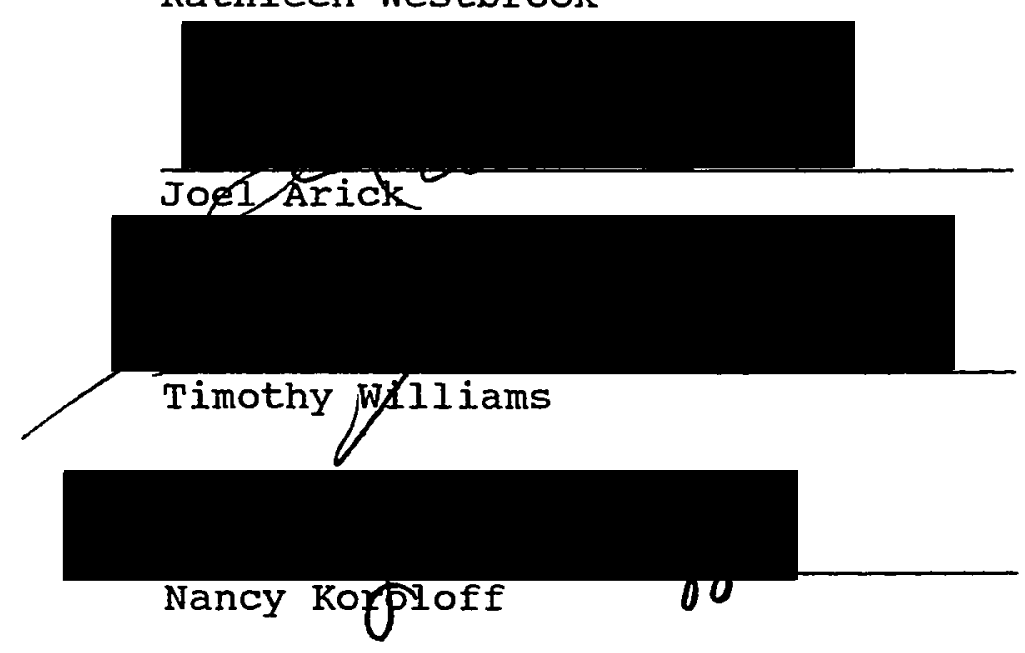

APPROVED:

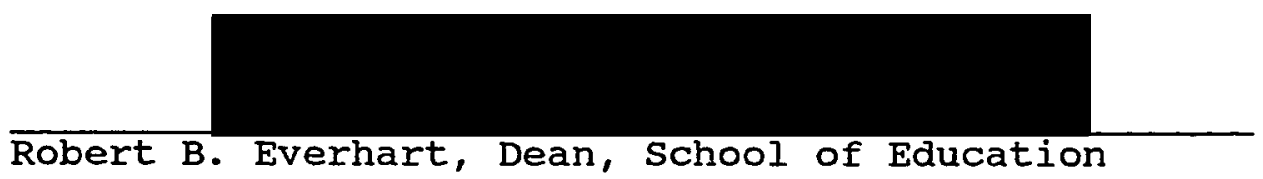

Robert B. Everhart, Dean, School of Education

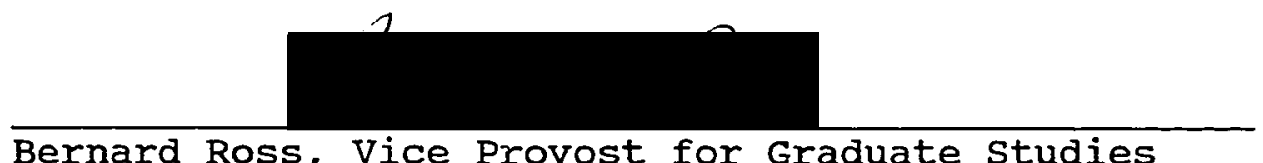


AN ABSTRACT OF THE DISSERTATION OF Patricia Ann Boles for. the Doctor of Education in Education Leadership presented April 19, 1989.

Title: Collective Bargaining for Educational

Administrators: Oregon and Washington Principals' Perceptions of Working Conditions

APPROVED BY MEMBERS OF THE DISSERTATION COMMITTEE:

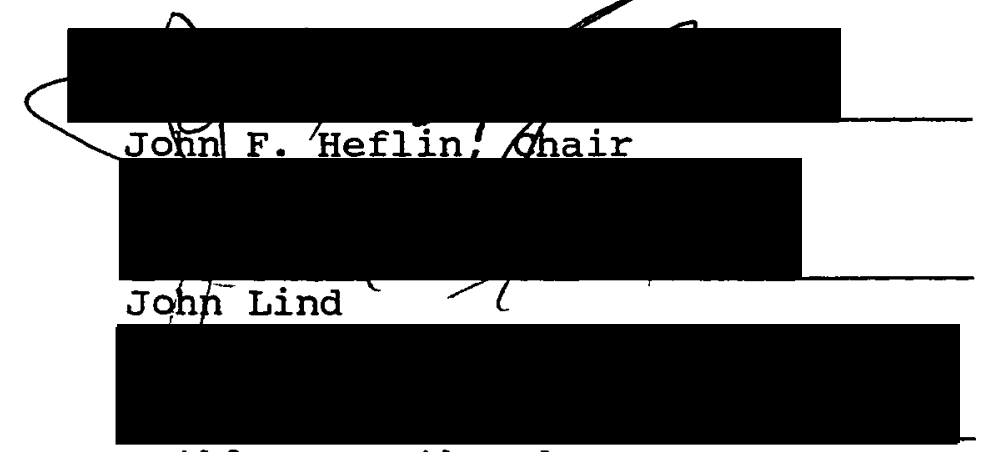

Kathleen Westbrook

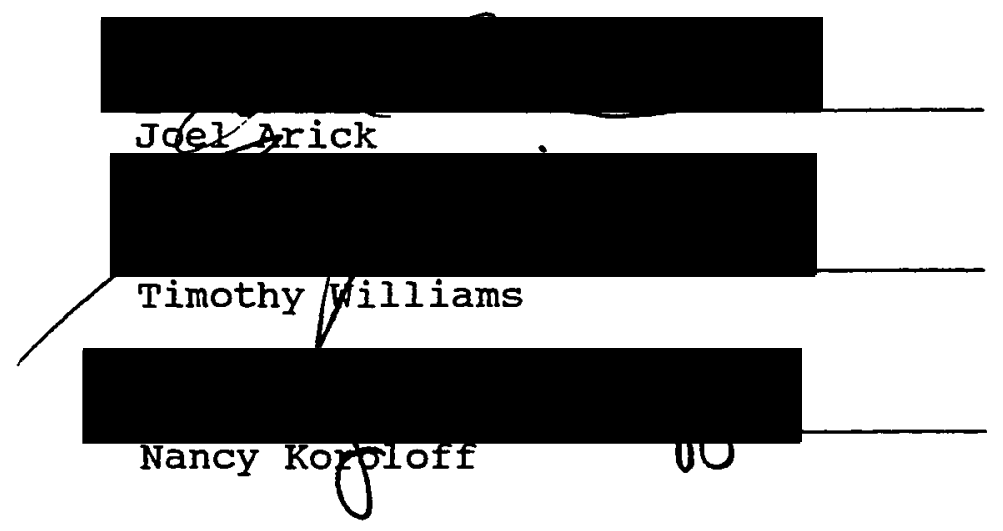

The purpose of this study was to examine the relationship between collective bargaining for public school principals and principals' perceptions of their working conditions. 
Specifically, this study examined the perceptions of working conditions for a sample of principals who had statutory authority to bargain collectively (Washington) and a sample of principals who did not have such authority (Oregon). This type of study can make a contribution to the knowledge base for educational leadership, administrative behavior and governance dynamics within educational organizations.

Methodologically, this descriptive study utilized a survey research design. Survey research permits data gathering from a relatively large number of cases at a particular point in time. This research strategy focuses primarily upon the generalized characteristics of a population rather than individual characteristics. The population for this study were principals in Oregon (908) and Washington (1102). The instrumentation for data collection was The School Principal's Working Conditions Questionnaire which was mailed to a sample of one hundred principals in oregon and one hundred in washington. The return rate for oregon was sixtyseven (67) percent and eighty (80) percent for Washington. Seventy-three and one half (73.5) percent of the principals responded to the questionnaire.

Nine sub-scales were used to measure determinants of principal's working conditions: 1) salary, 2) existence of formal written contracts, 3) autonomy, 4) power and authority, 5) job security, 6) fringe benefits, 7) role 
definition, 8) communications with superintendents and school boards, and 9) involvement in decision making.

The data analysis compared responses of two principals groups; an analysis of variance was used to identify significant differences between the two groups means. A major conclusion of the study was that there was no significant difference in perceptions of working conditions for the two groups of principals. Of the nine determinants of principals' working conditions, only autonomy was found to be significantly more positive for non-bargaining principals.

Non-bargaining principals (Oregon) perceived that they have greater autonomy in their management roles than do the bargaining principals. An explanation for this finding may be that Oregon Principals, although they have no impact on district collective bargaining processes, have a considerable amount of discretion in managing their schools and they have an impact upon teaching behavior and student learning outcomes.

A secondary data analysis compared the level of bargaining - formal, informal, and unilateral decision making to nine determinants of principal's working conditions. This analysis found salary (.001), involvement in decision making (.03), job security (.013), and fringe benefits $(.016)$ to be statistically significant. The group of principals who indicated they formally bargain had a significantly higher mean score than the informal collective bargaining or 
unilateral decision making groups. This finding suggests there may be a positive relationship between adequacy of salary, formal collective bargaining, and higher levels of job satisfaction.

with regard to involvement in decision making, job security and fringe benefits, the informal bargaining principals' group had a significantly higher mean score than the formal bargaining and unilateral decision making groups. The informal bargaining group perceived that they were involved in decision making processes more often or to a greater extent than principals in the formal and unilateral decision making groups. These decisions include policies and procedures which effect job security and fringe benefits. Consequently the higher scores for principals in the informal decision making group may be reflective of their participation in an inter-active "administrative team" model.

This study's findings has implications for legislative bodies who are developing and/or amending collective bargaining statutes. In addition, the study's findings can inform local policy makers as they develop policies and practices for involvement of principals in matters which relate to working conditions.

School district officials who have the responsibility for policy implementation can benefit from the knowledge that formalized collective bargaining (with the exception of possible salary issues) may not be as important as 
establishing structures and processes for including principals in decision making.

In summary, the major finding that there is no significant difference in perceptions of working conditions for the non-bargaining and bargaining principal groups, has powerful implications for the collective bargaining movement and for principals in the Northwest. 


\section{ACKNOWLEDGEMENTS}

There are many people who contributed both directly and indirectly in the completion of this dissertation.

First of all this study would not have been completed without the support and encouragement of my advisor and Chairman, Dr. John F. Heflin. I also appreciate very much the help of the other members of my committee: Dr. Jack Lind, Dr. Joel Arick, Dr. Kathleen Westbrook, Dr. Nancy Koroloff, and Dr. Tim Williams. They offered many useful suggestions and were always available when I needed assistance.

A note of appreciation is also due to Connie Gazow. Without her word processing, typing expertise and patience, this dissertation would never have been completed.

A note of sincere thanks and appreciation to Lori (Agar) Iethlean for her help and support as a friend and second mother to my son Brian, when I had classes, meetings or other time commitments. I knew he was always secure with her and this encouraged me to keep going.

Finally, I deeply appreciate the help, understanding and support given to me by my husband, sid; my son Brian, and my mother, Nancy Pearson. Without their cooperation, help, and support, this study would have been impossible. 
TABLE OF CONTENTS

PAGE

ACKNOWLEDGEMENTS $\ldots \ldots \ldots \ldots \ldots \ldots \ldots \ldots \ldots \ldots \ldots \ldots \ldots \ldots \ldots$

LIST OF TABLES $\ldots \ldots \ldots \ldots \ldots \ldots \ldots \ldots \ldots \ldots \ldots \ldots \ldots$ vii

LIST OF FIGURES $\ldots \ldots \ldots \ldots \ldots \ldots \ldots \ldots \ldots \ldots \ldots \ldots \ldots$

CHAPTER

I INTRODUCTION $\ldots \ldots \ldots \ldots \ldots \ldots \ldots \ldots \ldots \ldots \ldots \ldots$

Statement of the Problem .......... 4

Purpose of the study ............. 6

Definition of Terms ............ 8

Hypothesis ................... 9

scope $\ldots \ldots \ldots \ldots \ldots \ldots \ldots \ldots \ldots \ldots \ldots \ldots . \ldots \ldots$

summary $\ldots \ldots \ldots \ldots \ldots \ldots \ldots \ldots \ldots \ldots \ldots$

II REVIEW OF THE LITERATURE .............. 13

Introduction $\ldots \ldots \ldots \ldots \ldots \ldots \ldots \ldots$

Concepts of Organization .......... 14

The Historical Background of Collective Bargaining in the United States .. 22

A Review of Federal Law Related To Federal Employee Collective

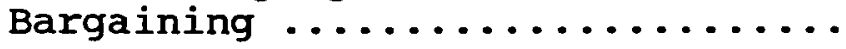

Review of the Development of Collective Bargaining in Public Education ...

Review of the Development of Collective Bargaining in oregon and Washington

Review of the Development of Collective Bargaining for School Principals. 
summary $\ldots \ldots \ldots \ldots \ldots \ldots \ldots \ldots \ldots \ldots \ldots . . \ldots$

III RESEARCH METHODOLOGY AND PROCEDURE........ 41

Introduction ................. 41

The Research Design .............. 41

Research Methodology ............. 42

Research Question ............... 46

Hypotheses ................... 46

Control variables ............... 49

The Population and Study Sample ..... 50

Sampling Procedure .............. 52

Study Procedures ................ 52

Instrumentation .............. 53

Statistical Analysis ............ 58

Summary $\ldots \ldots \ldots \ldots \ldots \ldots \ldots \ldots \ldots \ldots . \ldots . \ldots 6$

IV ANALYSIS OF THE DATA ............... 61

Primary Analysis ............... 61

Secondary Analysis .............. 68

Demographic Data Analysis ......... 84

Summary $\ldots \ldots \ldots \ldots \ldots \ldots \ldots \ldots \ldots \ldots . \ldots . \ldots$

V FINDINGS, CONCLUSIONS, AND RECOMMENDATIONS 100

study summary ................ 100

Findings .................... 109

Conclusions ................. 113

Implications ................ 117

Recommendations ............... 120

summary $\ldots \ldots \ldots \ldots \ldots \ldots \ldots \ldots \ldots \ldots \ldots . \ldots . \ldots 123$ 


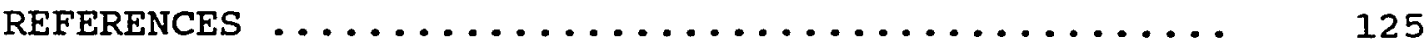
APPENDICES

A TRANSMITTAL LETTERS ................ 131

B QUESTIONNAIRE $\ldots \ldots \ldots \ldots \ldots \ldots \ldots \ldots \ldots \ldots \ldots . \ldots . \ldots . \ldots$

C ADDITIONAL STATISTICAL DATA ........... 140 


\section{LIST OF TABLES}

TABLE

PAGE

I. Levels of Significance as Determined by a One-way Analysis of Variance on the Nine Sub-hypotheses Regarding Bargaining and Non-Bargaining Principal and Their Perceptions of Working Conditions ........

II. Levels of Bargaining Indicated by Principals' Responses .......................

III. Analysis of Variance on the Nine Hypotheses Regarding Level of Bargaining and Principals' Perceptions of Working Conditions ........ 72

IV. Description of Demographic Data for the Study 85

V. Levels of Significance as Determined by a ChiSquare Analysis of Bargaining and Nonbargaining Principals and the Demographic Factor $\ldots \ldots \ldots \ldots \ldots \ldots \ldots \ldots \ldots \ldots$

VI. Chi-Square Test of Significance Comparing Bargaining and Non-bargaining Principals with the Demographic Variable of District classification $\ldots \ldots \ldots \ldots \ldots \ldots \ldots \ldots \ldots$ 
VII. Level of Significance as Determined by a One-way Analysis of Variance of District Classification and Working Conditions Found significant $\ldots \ldots \ldots \ldots \ldots \ldots \ldots \ldots \ldots$

VIII. Chi Square Test of Significance Comparing Bargaining and Non-bargaining Principals with District size $\ldots \ldots \ldots \ldots \ldots \ldots \ldots \ldots \ldots$

IX. Level of Significance as Determined by a One-Way Analysis of Variance of District size and Working Conditions Found significant $\ldots \ldots \ldots \ldots \ldots \ldots \ldots \ldots \ldots \ldots$

x. Analysis of Covariance of District size and District Classification and The Six Significant Determinants of Working Conditions $\ldots \ldots \ldots \ldots \ldots \ldots \ldots \ldots \ldots$

XI. Summary of Significant Determinants of Working Conditions in Each Analysis ..... 


\section{LIST OF FIGURES}

FIGURE

PAGE

1. Maslow's Hierarchy of Need .............

2. Framework of Labor Law in Private and Public Domain ..................... 26

3. Diagram of Research Study Design ........ 42

4. Schematic Diagram of the Research Model .. 45

5. Nine Determinant Area Question Distribution 56

6. Histogram of Principal's Perceptions Regarding the Existence of Formal

Written Contracts $\ldots \ldots \ldots \ldots \ldots \ldots \ldots \ldots$

7. Histogram of Principal's Perceptions Regarding autonomy $\ldots \ldots \ldots \ldots \ldots \ldots \ldots \ldots$

8. Histogram of Principal's Perceptions Regarding Salary and Level of Collective Bargaining ..

9. Histogram of Principal's Perception Regarding Power and Authority with Collective Bargaining Level

10. Histogram of Principal's Perceptions Regarding Job Security with collective Bargaining Level $\ldots \ldots \ldots \ldots \ldots \ldots \ldots \ldots \ldots$

11. Histogram of Principal's Perceptions Regarding Fringe Benefits with Collective Bargaining Level $\ldots \ldots \ldots \ldots \ldots \ldots \ldots \ldots \ldots \ldots \ldots \ldots$ 
12. Histogram of principal's Perception Regarding Role Definition with Collective Bargaining

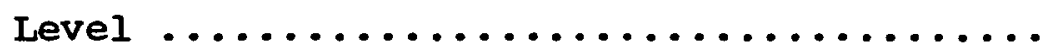

13. Histogram of Principal's Perceptions Regarding Decision Making With Collective Bargaining Level $\ldots \ldots \ldots \ldots \ldots \ldots \ldots \ldots \ldots \ldots \ldots . \ldots . \ldots$ 
CHAPTER I

INTRODUCTION

Collective bargaining has become an integral part of American public education governance. However, treatment of school supervisors and administrators in public education collective bargaining differs from private sector bargaining. Private sector supervisors and managerial employees are unrepresented in the collective bargaining process.

Public school administrators in states, such as Minnesota, New York and Massachusetts (Pisapia, 1980), have engaged in collective bargaining, with statutory protection. Conversely, public education administrators in Florida, Pennsylvania and Wisconsin, have been denied the right to engage in collective bargaining by statutes which specifically exclude supervisors and administrators from the protection offered to teachers (Pisapia, 1980).

The number of public school principals who collectively bargain has increased during the past decade (Nasstrom and Pier, 1983). Some observers believe the acceleration of administrative bargaining in public education will continue at its current rate of increase (Nasstrom and Pier, 1983). Twenty five years ago unions of administrators were nonexistent (Cooper, 1979) and the attitude and acceptance of the legitimacy of administrative collective bargaining was unified 
against bargaining rights for administrators (Cooper, 1979). The number of administrator bargaining units is still on the increase in a few geographical areas. Recently, the Philadelphia Association of School Administrators voted to join the teamsters to "aid the principals in getting a fair and equitable contract" (Rodman, 1986). They have subsequently become locked in a dispute with the school district over a two year period on salaries and other concerns. Presently, Pennsylvania state law guarantees no right to administrative collective bargaining (Rodman, 1986), but does provide a legal right to strike.

oregon excludes supervisors from inclusion under its Collective Bargaining Act. This exclusion is accomplished by a description of those defined by the Act as public employees. The law describes a public employee as "an employee of a public employer but does not include elected officials, persons appointed on boards or commissions or persons who are confidential employees or supervisory employees" (state of Oregon, 1982).

The law describes a Supervisory employee as:

any individual having authority in the interest of the employer to hire, transfer, suspend, lay-off, recall, promote, discharge, assign, reward or discipline other employees, or having responsibility to direct them, or to adjust their grievances, or to effectively recommend such action, if in connection with, the exercise of such authority is not merely routine or clerical in nature, but requires the use of independent judgement. However, the function of authority enumerated in the subsection does not necessarily require the conclusion that the individual exercising that function is a supervisor within the meaning of ORS 240.060 (Oregon Revised 
statutes, 1982, p. 37).

In Oregon, supervisory status is not established by title in the law but by the specific functions of the position within the organization. A title in one school district may be a supervisory position whereas the same title in another district would not be a supervisory position.

While Oregon excludes administrators' bargaining rights through the definition of public employee, a washington state statute excludes only the superintendent, assistant superintendent and directors of business by definition. Washington state grants administrators, with supervisory authority, bargaining rights through inclusion within the definition of "public employee" (Pisapia, 1980).

This statute prohibits "managerial" bargaining through categorical and definitional schemes. Washington statute does not exclude bargaining by administrators falling outside of these categories, nor does it provide specific definitions of supervisors, unless they fall outside of a bargaining unit. It only prohibits managerial bargaining through specific categorical exclusions (Pisapia, 1980, p. 68).

The statute's purpose is to prescribe certain rights and obligations of the educational employees of school districts in the state of Washington, and to establish procedures governing the relationship between these employees and their employers. They are designed to meet the special requirements and needs of public employment in education (state of Washington, 1975, 1st ex.s.c 288 2.). The statute goes on to define the term "employee organization" to mean any 
organization, union, association, agency, committee, council, or group of any kind in which employees participate, and which exists for the purpose, in whole or in part, for collective bargaining with employers.

The terms "employee" and "educational employee" mean any certificated employee of a school district, except: (a) The chief executive officer of the employer, (b) The chief administrative officers of the employer, which shall mean the superintendent of the district, deputy superintendents, administrative assistants to the superintendent, assistant superintendents, and business manager. Title variation from all positions enumerated in this subsection (b) may be appealed to the commission for determination of inclusion in, or exclusion from, the term "educational employee" (State of Washington, 1975).

Understanding the differences in working conditions between principals who choose, or are allowed, to bargain collectively and those who do not, may provide insight into the human relations of future organizational governance dynamics within education in the United States.

\section{STATEMENT OF THE PROBLEM}

The role of school principals in a school district is that of middle manager. Yet, questions arise with regard to their status as management or supervisory personnel or something all together different.

Middle level managers, in many school districts, do not have similar access to negotiated decision making as do their subordinates (teachers) who are involved in collective bargaining (Caldwell and Paul, 1983). This decision making 
process with respect to wages, benefits and self-interest is an acceptable practice in a majority of public and private sector work places. Upper management (boards and superintendents) tend to hold more tightly to unilateral onesided decision making due to negative attitudes produced as an outgrowth of teacher bargaining. A healthy organizational climate is premised on "trust" (Likert, 1967). Evidence would indicate principals excluded from direct input or participation in a process for determining wages and fringe benefits, will be less likely to accept and understand the motives and intentions of the school board (Caldwell, 1983). It seems incongruous that principals -- instructional leaders accountable for the welfare and educational growth of the nation's youth -- should in some school districts be excluded from meaningful participation in matters impacting directly on their personal welfare (Caldwell and Paul, 1983).

Due process, according to oregon and Washington state law, affords a level of job security to principals. Certain job requirements, e.g. teacher evaluation procedures, in which they have less direct input than the teachers, make contracts difficult to administer. Principals are evaluated and have less authority in developing the process and contract than their subordinates. Principals are "caught in the middle". They do not have direct access to formalized channels of input with their governing boards in defining the terms and conditions of their work. 
PURPOSE OF THE STUDY

The most often claimed advantages to principals bargaining involves both personal and organizational benefits. Principals may receive higher salaries and better fringe benefits; more extensive employment rights; seniority provisions in case of lay-offs; better communication with the superintendent and the school board; greater authority on the job; and opportunities to achieve resolution on internal disputes through effective grievance procedures. Presumably, districts become more efficient and compatible organizations by their inclusion.

Collective bargaining fails, according to some, in its organizational impact. Principals have less authority and greater breakdowns with superordinates in communication, as well as more conflict and greater difficulties in resolving disputes (Nasstrom and Pier, 1983). Proponents of the "administrative team" concept feel these to be the major victims of principals' rights to collectively bargain. The adversarial aspects of bargaining make achieving the purposes of an "administrative team" impossible.

Collective bargaining for administrators in oregon and Washington differs according to the statutes in place in each state. Comparing principals' perceptions of their working conditions through a sample of principals permitted bargaining rights and a sample of those not permitted such rights could 
provide clearer direction to those involved in the establishment of state statutes affecting bargaining rights. In addition, this comparison may provide insight into future administrative structures for school districts in washington and Oregon.

This study examined the perceptions of public school principals in oregon and washington regarding their perceptions of working conditions and analyzed the relationships between principals' perceptions and the ability to collectively bargain. This study also investigated the degree of formality in bargaining and whether it impacts these perceptions.

The perceptions of working conditions were determined by examining nine determinants:

1. Salary - Adequacy of Salaries

2. Formal Contracts - Existence of written contracts, policy statements, or memoranda of understanding and agreement

3. Autonomy - Principals authority over teachers and school building activities

4. Power and Authority - Specific statements of principal's decision making areas

5. Job Security - Specific seniority provisions, grievance procedures

6. Fringe Benefits - Professional membership dues, paid and unpaid leave policies, and release for professional growth

7. Role Definition - statement of both the board's and principal's rights and responsibilities 
8. Communications with board/superintendent Effectiveness of principal's communication and ease of resolution of disputes between board/ superintendents

9. Involvement in decision making - The extent to which principals are involved in setting policy (Williams, 1985, p. 2)

\section{DEFINITION OF TERMS}

For the purposes of this study, the following operational definition of major terms are:

Collective Bargaining - the mutual obligation of the public employer and the exclusive bargaining representative, to meet, confer and negotiate in good faith, and to execute a written agreement with respect to grievance procedures, and collective negotiations on personnel matters, including wages, hours, and working conditions which may be peculiar to an appropriate bargaining unit of such public employer (State of oregon, 1982).

Administrators - public education officials with any responsibility for or having authority in the interest of an employer, to hire, assign, promote, transfer, layoff, recall, suspend, discipline, or discharge other employees, or to adjust their grievances, or to recommend effectively such action when such action is not merely routine or clerical in nature but calls for the consistent exercise of independent judgement (state of Washington, 1975, 1st ex.s.c 288).

Principal - public education administrator with responsibility for a school building and all it's functions inclusive of the evaluation of certificated employees specifically elementary school principal, junior high or middle school principal and senior high school principal (state of Washington, 1975).

Perceptions - awareness of the elements of the environment through direct or intuitive recognition; the integration of impression of events derived from past experience and serving as a basis for or as verified by further meaningful motivated action (Webster, 1986, p. 1675). 
Working Conditions:

1. Salary - Adequacy of Salaries

2. Formal Contracts - Existence of written contracts, policy statements, or memoranda of understanding and agreement

3. Autonomy - Principals authority over teachers and school building activities

4. Power and Authority - specific statements of principal's decision making areas

5. Job Security - Specific seniority provisions, grievance procedures

6. Fringe Benefits - Professional membership dues, paid and unpaid leave policies, and release for professional growth

7. Role Definition - statement of both the board's and principal's rights and responsibilities

8. Communications with board/superintendent Effectiveness of principal's communication and ease of resolution of disputes between board/ superintendents

9. Involvement in decision making - The extent to which principals are involved in setting policy (Williams, 1985, p. 2)

HYPOTHESIS

The research indicates collective bargaining for educational administrators is afforded to middle managers, at least in a permissive process, in school districts in thirtyone (31) states (Cooper and Nakamura, 1983). Washington's statutes allow for this process, but oregon statutes deny the formalized process. 
For this study, it was hypothesized principals' perceptions of their working conditions do not significantly differ even though statutes regarding the collective bargaining rights of principals in both states differ greatly.

The trend in public education is toward an increase in administrator collective bargaining (Bridges and cooper, 1976). This study provided additional insights into these issues for educators and legislators of other states who are also concerned with the phenomenon of administrative unionization within public education.

SCOPE

This study was limited to a random sample of public school principals $(K-12)$ in the states of Washington and oregon who serve solely as building level administrators. The perceptions of principals rather than actual level of salaries and fringe benefits were studied. As Caldwell and Paul's (1983) previous evidence suggests, the process through which working conditions such as salaries are determined may be more crucial to the organization because job satisfaction is not always tied to monetary benefits.

The sample for this study included one hundred (100) principals in oregon and one hundred (100) principals in Washington representing a ten percent (10\%) sample of the total population available for study.

Data for the study were collected between February and 
March 1988. The research instrument, "School Principals' Working Conditions Questionnaire", developed orginally by Williams (1985) and Morris (1985) and combined for this investigation, was used for the data collection activities (See Appendix B). There are several limitations of this study:

1. This study is confined to perceptions of the working conditions of school principals in the states of Oregon and Washington.

2. To maximize a true representation of the population, principals surveyed were randomly chosen. 3. No attempt was made to survey the perceptions or attitudes of school district top management with regard to principals' working conditions.

4. This study only examines perceptions of working conditions by school principals and the effects of collective bargaining on their perceptions.

5. This study did not examine the attitude of school principals toward collective bargaining, nor the effects of collective bargaining on principals' working conditions, nor the actual working conditions of principals. 
SUMMARY

This study focused on collective bargaining as a defined and structural approach affecting principals' perceptions of their working conditions and thus influencing the operation of their educational organizations. In many states, administrator groups have attempted to improve working conditions by lobbying for collective bargaining rights.

Chapter I reviews how Oregon and Washington differ with regard to principals' statutory authority to collectively bargain and the perceived impact of collective bargaining on working conditions. Nine catagories of working conditions were defined and the concepts utilized in this study were operationally defined.

In Chapter II, the historical development of the American labor movement is traced and specific studies related to collective bargaining and school principals are reviewed. 
CHAPTER II

REVIEW OF LITERATURE

INTRODUCTION

organization theory and the history of the American labor movement have greatly influenced the right of school principals to organize for the purpose of collective bargaining. This chapter reviews this history and selected previous studies in this field. This chapter is divided into the following sections:

1. Concepts of Organizations

a. Working Conditions

b. The Concept of Authority

c. The Concept of Power

d. Exchange Theory

e. Early Collective organization

f. The Concept of Collective Bargaining

2. The Historical Background of collective Bargaining in the United states

3. A Review of Federal Law Related to Federal Employee Collective Bargaining

4. A Review of the Development of Collective Bargaining in Public Education

5. A Review of the Development of Collective Bargaining in Oregon and Washington

6. A Review of Research Related to collective Bargaining and School Principals 
CONCEPTS OF ORGANIZATIONS

\section{Working Conditions}

Caldwell and Paul (1983) state Maslow (1954) and Herzburg's (1966) theories support the need for principals to achieve higher order need satisfactions. Maslow's theory is based on the idea that motivation is an internal force which cannot be imposed by external effort. People are continually seeking to satisfy a hierarchy of needs. Maslow states managers should strive to create an environment in which employees can achieve self actualization and the maximum effectiveness permitted by one's abilities and skills (Lutrin, 1985). Frederich Herzberg found that contented workers derive satisfaction directly from job satisfiers and motivators. These motivators include the work itself as well as responsibility, achievement, recognition, advancement and growth. Unhappy workers found dissatisfaction from the job context and hygiene factors. According to Lutrin (1985) these factors relate to Maslow's lower levels of need (working conditions, interpersonal relationships, salary, status, job security) which must be satisfied before self actualization can be achieved (see Figure 1). When school boards openly discuss with principals and act on relevant concerns such as wages, role definition, autonomy and scope of authority, it may enhance in principals a greater sense of professional recognition and esteem (Caldwell and Paul, 1983). 


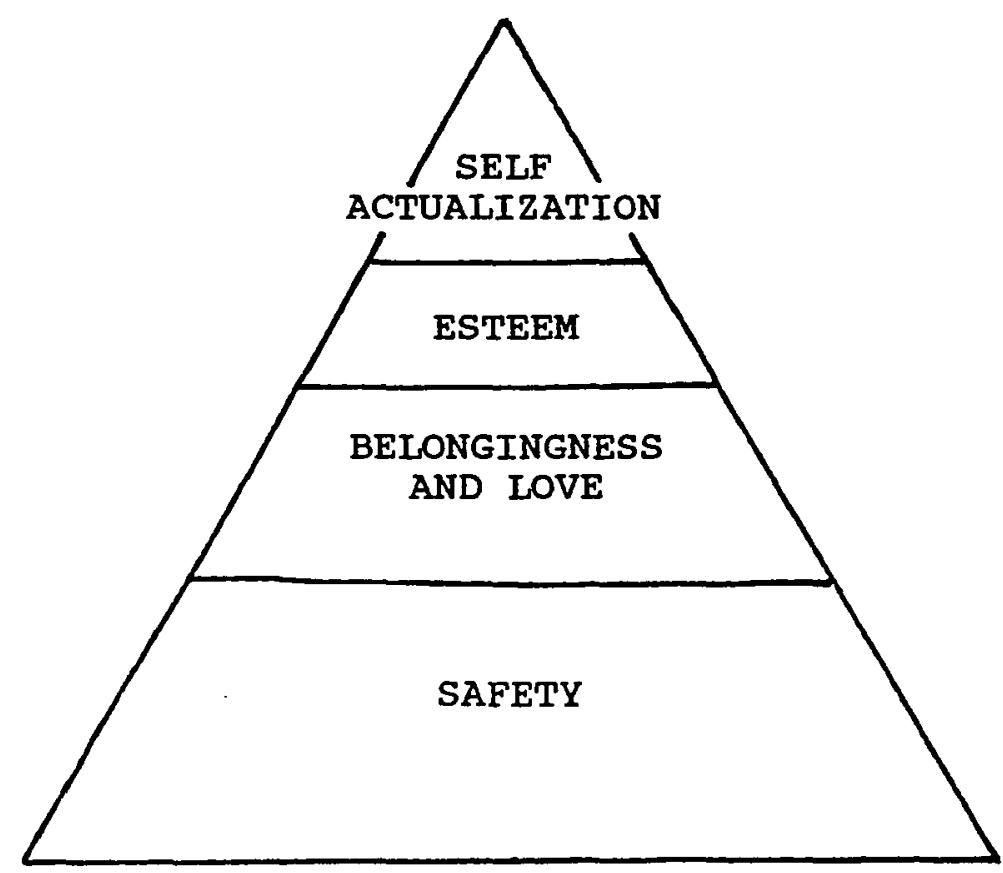

Figure 1. Maslow's hierarchy of need.

The Concept of Authority

Talcott Parsons defines authority as an aspect of power in a system of social interaction. It is institutionalized power over others (Parsons, 1954).

Authority is a formal concept and comes from a formal organization (Hicks, 1967). From the basic definition of authority, as a right to act or direct the actions of others, two characteristics are given: (1) authority is a right and (2) as a result of possessing the right, one is entitled and obligated directly or indirectly to act. A third characteristic is implied and involves the power to employ penalties or sanctions so that a desired action is completed (Bierstedt, 1964). 


\section{The Concept of Power}

Power is a broad concept which is not necessarily confined to organizations. It is neither completely formal nor informal in nature, though it can be influenced by factors including an individual's ethical and moral considerations (Sisk, 1979) .

According to Max Weber, power is the probability that one actor within a social relationship will be in a position to carry out his own will despite resistance (Weber, 1947). "The ability to get things done the way one wants them to be done," according to Gerald P. Salanch and Jeffrey Pfeffer (Salancih and Pfeffer, 1977, p. 17). Power is the ability of a person to do something measured in terms of his or her ability to (1) give reward, (2) promise rewards, (3) threaten to withdraw current rewards, (4) withdraw current rewards, (5) threaten punishment, or (6) punish (Hicks, 1967).

It is the realistic capacity of a system-unit to actualize its interests (attain goals, prevent undesired interference, command respect, control possessions, etc.) within the context of system-interaction and to exert influence on processes in the system (Parsons, 1954).

\section{Exchange Theory - Power and Authority}

At the base of self actualization are human needs and pleasures which have their roots in social life. Whether we think of power, professional recognition, or sociable 
companionship, the comforts of family life or the challenge of competitive sports, the gratifications experienced by individuals are contingent upon the actions of others. The rewards individuals obtain in social associations entail a cost to other individuals, not to the point in which the gains of some depends upon the losses of others, but rather that individuals associate with one another because they all profit from the social association. They do not all profit equally nor do they share the cost of providing the benefits equally. The fact that furnishing benefits to others produces social rewards is a major reason people often go to great lengths to help associates and enjoy doing so (Blau, 1978).

Individuals strive to achieve diverse objectives. The idea of selecting the most preferred among available alternatives does not imply the one chosen always yields the greatest material profit (Blau, 1978). Choice of an alternative that requires making material sacrifices but contributes most to the attainment of some ideal, may be their objective. Even in this choice errors may occur. The need to anticipate, in advance, the social rewards with which others will reciprocate in exchange relations inevitably brings uncertainty and errors. Given this situation, the assumption that men seek to adjust social conditions to achieve their ends is realistic and inescapable (Blau, 1978). The basic social processes governing associations among people are rooted in simple psychological processes such as 
the underlining feelings of people and their desires for various kinds of rewards. The psychological needs of individuals determines which rewards are important and to whom they are attracted. This mutual attraction depends on anticipating the association will be rewarding. The process of social attraction leads to the process of social exchange. This situation occurs frequently when one individual needs something another has to offer, such as help in work but has nothing the other needs in reciprocation for that help. The person in need of the recurrent services forces the other to help, gaining help from another source or getting along without the help. If unwilling to choose any of these alternatives, individuals must subordinate themselves to others and comply with their wishes, thereby rewarding the individual with power as an inducement for furnishing the needed assistance.

Exchange processes give rise to differentiations of power. A person who commands services others need, attains power over others by making the satisfaction of their need contingent on their compliance. An employer can make workers comply because they are dependent on the wages received. There are differences in the dynamics of this power in a collective situation and the power of one individual over another. Collective approval of power legitimatizes power and its disapproval brings opposition.

Specific forms of social organization emerge as a result 
of the process of exchange and competition in which the patterns of conduct by individuals and groups and their relations adjust. Power is the resource which makes it possible to direct and coordinate the activities of people (Blau, 1978).

stable organizing power needs legitimation and an important function of legitimate authority is to organize collective effort on a large scale in the pursuit of commonly accepted ends. Union organizations are designed to further the common objectives of their memberships.

The organization of collective effort mobilizes power. Power can mean different things to different people, but is based on the action of people in social associations and their social exchanges.

\section{Early Collective organizations}

organization involves the coordination of collective effort. Man is by nature a political animal (Cresswell and Murphy, 1976). Political - that all men tend to gather in a "polis", in a natural grouping where through a process of politics in a politz, to work out their policies. This assumes man is instinctively and by nature a herd animal, a creature of the polis, congregating compulsively with those of his kind (Cresswell and Murphy, 1976).

In the ancient cities of Sumeria, the priesthood was the first class to organize, the warriors formed their "union" 
called the nobility and the professionals organized the colegii: medicine, teaching, and law. Lesser occupations also organized, especially among the more skilled labor aristocracy.

In ancient Mesopotamia, citizens working for the temple organized in groups. Among the early Hebrews, families employed in the same craft formed clans (guilds). In ancient Greece a craft belonged to a family or clan, and in Rome there were colegic of occupational groups that gave them force in time of need for safeguarding their common interests. In Medieval Europe, guilds were organized to aid members as they became more interested in economics. All of these organizations probably had grievances, complaints, work stoppages and social pressuring but the continuing reason for these organizations were the "communal compulsion" (Cresswell and Murphy, 1976) of the like to work together. In early societies with caste systems, the coming together or organizing of people in a craft or trade was relatively easy but in more fluid and open societies, such as the United states, the coming together of the "occupational clan" (Cresswell and Murphy, 1976) has been more difficult. Whenever any sector of the labor force becomes sufficiently aware of its collective presence and power, it sooner or later organizes (Cresswell and Murphy, 1976). 


\section{Collective Bargaining}

Under a historic concept of governmental sovereignty, top management was obligated to make use of a proper balance between the rights of its employees and the greater common welfare of the public. The engagement in the bilateral process of determining conditions and terms of work for middle management was discouraged (Caldwell and Paul, 1983).

The suspicion that workers are unable to show sound judgement in issues and matters relating to their personal welfare as organizational climate becomes more structured and formalized, grows stronger as a consequence of the collective negotiations process and is not in alignment with research findings. The idea that the organization becomes increasingly strained, bureaucratic and adversarial and is not founded with current findings (Kanner, 1977; Karlitz, 1978, and Smith, 1973). Caldwell's data appears to indicate perceptions of workers can be positively influenced through a collective bargaining approach. This approach should be mutually defined and structured, in establishing aspects of work relationships including monetary compensations (Caldwell, 1983). School principals, today, often experience doubts about their leadership style as our nation's schools suffer a serious loss of public confidence, as articles and studies have emerged about violence in the schools, drugs, and declining student achievement (Dwyer, et al, 1987). The school principal has been thrust into the very center of the troubled educational 
arena by those who have studied "effective schools" (Edmonds, 1979). The erosion of the public's commitment makes it difficult for a principal to effectively manage a school. Community factors such as lack of parental support for programs, lack of tax funds, and insufficient budget resources all reflect a decline of public confidence in the school system (Pinkey, 1980 and Williams, 1985). Goldhammer (1971) found principals complained their power and autonomy as school leaders has decreased (Dwyer, 1987).

To counteract this loss of status and control, many principals have chosen to engage in collective bargaining activities, formed independent unions and even affiliated with the Teamsters and AFL-CIO (Williams, 1985 and Yeager, 1974).

\section{THE HISTORICAL BACKGROUND \\ OF COLLECTIVE BARGAINING IN THE} UNITED STATES

The trade movement and guild charters during the Industrial Revolution following the civil war are the precursors of collective bargaining in the United states. Labor shortages and the need for industrial expansion brought about the formation of labor organizations. Most early unions were poorly organized and short lived, especially during times of depression when any work was at a premium (Chamberlain, 1965).

In 1881, the American Federation of Labor (AFL) was founded. The AFL was a group of skilled workers united to 
promote higher wages, shorter hours, better working conditions and the right to collectively bargain. This union is a stronghold in the U.S. labor movement as it exists today. This union's membership, as well as other unions, grew until the great Depression of 1929 when a decline in American unionism took place.

With the numbers of unemployed workers as a public concern, national attention focused on the formulation of several federal, long term labor policies. This focus was the basis for most of the major federal labor relations statutes generated and amended over the years.

The act having the greatest effect on organized labor was the National Labor Relations Act of 1935. This act provides protection of employee groups against employer influence and makes it unfair for an employer to refuse to bargain with the authorized representative of the employee. All of the laws beginning with the Railway Labor Act continuing through the Labor - Management Reporting and Disclosure Act of 1959 continue to provide a basis for private sector collective bargaining and a legal basis for the relationship between employers and workers.

As legislative labor activity increased in intensity, public employees demanded greater bargaining rights. The American Association of School Administrators (AASA) reported in 1966, that 110 (one-hundred ten) teachers' strikes occurred between 1940 and 1962. In 1962, President John F. Kennedy 
issued Executive Order \#10988, "Employee - Management Cooperation in the Federal Service" which, was perhaps, the most important order in support of public employee bargaining. This order provided all federal employees the opportunity to bargain collectively (Hagburg and Levine, 1979).

THE REVIEW OF FEDERAL IAW RELATED TO FEDERAL EMPLOYEE COLLECTIVE BARGAINING

Executive order \#10988 did not exclude supervisor membership in labor organizations. The order guaranteed federal employees the right to join organizations of their choice, and these organizations were given informal, formal or exclusive recognition depending upon the proportion of eligible federal employees they represented.

Section $1(\mathrm{a})$ of "General Provisions" of the Kennedy order read as follows:

Each employee of the executive branch of the Federal Government has the right, freely and without fear of penalty or reprisal, to form, join, and assist a labor organization or to refrain from any such activity, and each employee shall be protected in the exercise of this right. Except as otherwise expressly provided in this order, the right to assist a labor organization extends to participation in the management of the organization and acting for the organization in the capacity of an organization representative, including presentation of its views to officials of the executive branch, the Congress, or other appropriate authority. The head of each agency shall take the action required to assure that employees in the agency shall take the action required to assure that employees in the agency are appraised of their rights under this section, and that no interference, restraint, coercion, or discrimination is practiced within his agency to encourage or discourage membership in a labor organization (Hungeford, 1982, p.9). 
Executive Order \#10988 stated collective agreements are negotiated between representatives of federal employee groups and federal agencies relative to personnel policies and working conditions. The order also authorized arbitration of grievances and contract interpretation or application. It prohibited recognition to organizations which asserted the right to strike against the United states government. The Executive order was the impetus behind states and local governments' development of collective bargaining techniques (Lieberman, 1970) .

Those organizational and barganining rights were further advanced by another Executive order, \#11491, signed in 1969 by President Richard M. Nixon. This order helped to coordinate, clarify, and strengthen Executive order \#10988. The major changes and additions related to an exclusive recognition election; definition of "good faith" bargaining; exclusion of supervisory personnel from joining an employee group; prohibition of union shop, agency shop or maintenance of membership; required financial disclosure; defined unfair labor practices.

The Civil Service Reform Act of 1978 established a Federal Service Impasse Panel for the purpose of impasse resolution; and established a Federal Labor Relations Authority to oversee the order's implementation (Hungerford, Bischof, 1986).

The Railway Labor Act of 1926, the National Labor 
Relations Act of 1935, The Executive order (along with the implemented state and local labor laws) and the civil service Reform Act of 1978 provide the framework for collective bargaining in private and public sectors (See Figure 2).

\begin{tabular}{|c|c|c|c|c|}
\hline & \multicolumn{2}{|c|}{ Private Sector } & $\begin{array}{l}\text { State And Local } \\
\text { Government }\end{array}$ & $\begin{array}{l}\text { Federal } \\
\text { Sector }\end{array}$ \\
\hline Law & $\begin{array}{l}\text { Railway } \\
\text { Labor Act } \\
\text { (RIA) } \\
\text { (RRs \& } \\
\text { airlines) } \\
1926\end{array}$ & $\begin{array}{l}\text { National } \\
\text { Labor } \\
\text { Relations } \\
\text { Act } \\
1935\end{array}$ & $\begin{array}{l}\text { State \& local } \\
\text { collective } \\
\text { bargaining } \\
\text { statutes }\end{array}$ & $\begin{array}{l}\text { Civil Service } \\
\text { Reform Act } \\
1978\end{array}$ \\
\hline $\begin{array}{l}\text { Collective } \\
\text { Bargaining } \\
\text { Process }\end{array}$ & $\begin{array}{l}\text { 1: Full } \\
\text { collective } \\
\text { bargaining } \\
\text { rights }\end{array}$ & $\begin{array}{l}\text { 1: Full } \\
\text { collective } \\
\text { bargaining } \\
\text { rights }\end{array}$ & $\begin{array}{l}\text { 1: Established } \\
\text { by state statute } \\
\text { ranging from } \\
\text { none to full }\end{array}$ & $\begin{array}{l}\text { 1: Limited } \\
\text { right to } \\
\text { bargain non- } \\
\text { economic } \\
\text { issues; no } \\
\text { right to } \\
\text { strike }\end{array}$ \\
\hline
\end{tabular}

Figure 2. Framework of labor law in private and public domain.

REVIEW OF THE DEVELOPMENT OF COLLECTIVE BARGAINING IN PUBLIC EDUCATION

The first formal association of educators was the National Teacher's Association. Its merger with the National Administrators group formed the National Education Association (NEA) (Cooper, 1982). As private industry labor strengthened, the American Federation of Teachers (AFT) was organized in 1916 to secure bargaining rights for teachers (Lieberman, 1970). Until the 1960 's, the two organizations had some real 
differences. One major difference was the AFT's exclusion of administrators as part of their membership, while the NEA allowed administrators to hold membership in the organization. While the AFT focused its emphasis on the economic status of teachers and proposed collective bargaining as early as 1935, the NEA focused its attention on improving teaching until 1964. After the early 1960 's, the differences between the two organizations lessened and both were recognized as providing the necessary support to collective bargaining. As early as 1961 in New York, and 1964 in cleveland and Detroit, bargaining rights were won for these cities' teachers. In July of 1965, the Public Employees Relations Act (PERA) was passed in Michigan. By 1970, thirty-eight states had enacted some type of bargaining or meet-and-confer legislation. Collective bargaining in public education had become a reality (Lieberman, 1970).

Presently, all public sector collective bargaining statutes authorize some form of bargaining by teachers and educational workers (Jascourt, 1984). Only in some areas of the south and West are there no bargaining provisions, although even in these areas some form of collective bargaining does take place. Most recently (1987), Illinois and Ohio enacted the most comprehensive collective bargaining provisions anywhere (Jascourt, 1984). Education reforms are not inconsistent with the principles underlying collective bargaining. The empowerment of teachers and principals within 
an educational organization cannot help but bring about reforms within educational organizations.

\section{REVIEW OF THE DEVELOPMENT OF COLLECTIVE BARGAINING IN \\ OREGON AND WASHINGTON}

Public employees in oregon enjoy collective bargaining rights under the Public Employee Collective Bargaining Act (PECBA), (State of Oregon, 1982). PECBA was established by the 1973 Oregon Legislative Session, but forerunners of this comprehensive collective bargaining legislation were in existence since the early 1960's (Hungerford and Bischof, 1982). Oregon's first public bargaining law was adopted in 1963 after unsuccessful attempts in 1959 and 1961. The 1963 legislation was amended, and revisions in 1965 removed teachers from its coverage and established a separate framework for their representation. The 1973 PECBA encompasses coverage for all public employees, including those in school districts. This law altered the oregon school Board process related to making decisions with teachers about their working conditions.

PECBA excludes supervisors from the provisions of the law and, therefore, principals are not included in bargaining units and are not represented in the collective bargaining process. Since its passage, there have been numerous cases in which the Employment Relations Board (ERB) applied the definition of supervisor to various administrative positions 
and established a clear delineation of these positions. The supervisory status in oregon is not established by title in the law but by the functions of the position within the organization. It appears clear the intent of PECBA is for public employees to receive the benefits of coverage to the greatest extent possible. The act also makes clear the intent of the legislature to exclude management (Thomas, 1981).

Washington State's Public Employee Collective Bargaining Act (PECBA) went into effect in 1967 covering all public workers. State statutes originally covered toll bridge operators in 1961 and expanded to cover public utility districts in 1963 and teachers in 1965. The 1965 statute required collective bargaining for teachers with exclusive representation awarded. school districts and the state Department of Public Instruction were required to develop appropriate policies and rules. No provisions were made for unfair labor practices or strikes. The final PECBA, in 1967, provided mediation services by the state and was reviewed by the PECBA committee in 1971 to include modifications for greater efficiency of the law with amendments. The specific guidelines for collective bargaining for teachers and administrators is contained in the state of washington: Revised Code of Washington Title 41: Public Employment, Civil Service and Pensions, Chapter 41.59. This Educational Employment Relations Act, prescribes the rights and obligations of educational employees of school districts of 
Washington and establishes the procedures governing the relationship between employees and employers. These procedures are designed specifically for the needs of public employment in education.

Chapter 41.59, Public Employees' Collective Bargaining, is consistent with Washington statute as a whole regarding bargaining. It provides for the continued improvement of the relationship between public employers and their employees by requiring a uniform basis of implementation of the rights of public employees to join labor organizations of their own choosing, and to be represented by organizations in matters concerning employment relations.

\section{REVIEW OF THE DEVELOPMENT OF COLLECTIVE BARGAINING FOR SCHOOL PRINCIPALS}

Attitudes, perpetuated and nurtured through time, are not readily dispelled even in the wake of clear evidence (Caldwell and Paul, 1983). This is the case with many of the present practices involving principals and school boards in the resolution of issues related to job function, and personnel policies and individual benefits. Resolving issues, especially those focusing on wage increment plans, fringe benefits and conditions of employment, are documented and set within an adversarial structure (Caldwell and Paul, 1983).

Over the last twenty-five years some of the issues which stir the greatest controversy in the labor movement occur in 
the public sector. The most unique of these are the collective bargaining rights of middle management personnel in education.

With the signing of Executive Order \#10988 (Hagberg and Levine, 1979), federal workers became eligible to bargain with management. Bridges and cooper (1976) in examining existing state statutes, noted analysis of rulings by state labor commissions, phone interyiews with state officials, comparisons of teacher and administrator contracts, and reviews of the limited literature on administrative bargaining are the three major trends in collective bargaining for school administrators:

1. The granting of bargaining rights to teachers is a necessary condition for granting similar rights to administrators.

2. The eligibility of administrators for collective bargaining is more often determined by job junction than job title.

3. The scope of negotiations is similar for administrators and teachers although the actual provisions of the negotiated contracts for the two groups show more striking differences than similarities (Bridges and Cooper, 1976, p. 307).

Bargaining activity occurs in thirty-one (31) states (Cooper and Nakamura, 1983). Seventeen of these provide administrators access to the bargaining process through enabling legislation, including Washington. More than $90 \%$ of the administrator bargaining units are in seven states: Connecticut, Massachusetts, Minnesota, Michigan, New Jersey, New York, and Washington (Bridges and Cooper, 1977). 
As of 1982, collective bargaining between school principals and other mid-rank supervisors and school districts occurred in about two-thousand one-hundred $(2,100)$ cases in thirty-one (31) states and the District of Columbia (Cooper and Murrmann, 1982).

Theodore J. Kowalski in an article for The American School Board Journal (1978), suggests Boards of Education are pushing their administrators toward collective bargaining by supplying "unintentional incentives that may be spurring administrators into such actions" (Kowalski, 1978, pg. 35).

Dr. Norman Barea, in a National Association of Secondary School Principals Bulletin (1978) suggests the following list of principals' concerns as leading to organizing: 1) Improved communications, 2) Security, 3) Due Process, 4) Improved wages, 5) Procedures for resolving concerns, 6) Hours, and 7) other conditions of employment (Barea, 1978, p. 44).

From the point of view of collective bargaining, the role of school boards and teachers appears clear. The position of principals in relation to these negotiations, however, is not so clear. As a result, there is frustration among administrators who see negotiations going on around them, but rarely with them (Cunningham, 1968). Bargaining between top management and teachers, in which principals neither participate nor are committed, has steadily undermined their prerogatives. Forty-five (45\%) percent of the principals participating in a study conducted by the NASB Journal staff 
(Cooper, 1976) reported this one fact alone.

It is not surprising the formal collective bargaining process has appeal to many principals. When viewing substantial gains in salary and other welfare issues made by teachers, principals feel anxious of the power and independence teachers develop through the collective bargaining process. Such results have appeal to principals who are not completely satisfied with their working conditions (Anderson, 1970).

A study executed by the National school Boards Association in 1976 queried a cross section of U.S. and Canadian principals regarding labor relations. Forty-eight percent $(48 \%)$ of those responding reported themselves as seriously at odds regularly or occasionally with their superintendent. Eighty-six percent (86\%) reported being in favor of state laws which guarantee their right to bargain with a school board (Cooper and Nakamura, 1983).

In a study of over five hundred districts in Michigan, Lecesne (1980) reported a positive relationship between principals and other school personnel in districts with formal negotiations. It concluded principals in formalized bargaining units view their relations with school boards, superintendents and other management personnel more favorably than those whose wages were determined through informal means, or who had no input into decisions.

Based on a sample of over five-hundred (500) secondary 
principals, LeCesne's findings suggest more than the actual level of salary, the process through which salaries are determined may be more crucial in predicting job satisfaction. Principals appear significantly more satisfied when they have input or consultation into their salary determination. one study determined and supported the notion that all input raises satisfaction levels over non participation roles (Caldwell, et.al, 1981). This suggests utilizing structural and formal elements in principal and board relationships increases the positive effects of job satisfaction for principals (Lecesne, 1980).

In a Michigan study (Caldwell, et al, 1981), which had a sample size of five-hundred (500) secondary principals, results suggested the process through which salaries are determined is more crucial to predicting job satisfaction than the actual level of salary. A positive correlation between the degree of formalized interaction of principals with school boards in determining compensation policies and principals' perceived level of role satisfaction, were found to be consistent with the earlier work of Lecesne (1980). The Lecesne study was designed to evaluate the effectiveness of collective bargaining between principals and school boards.

A study was conducted by Sweeney and Rowedder (1982), and surveyed principals in Iowa, where principal unions are prohibited by state statute and principals in connecticut, where more than eighty (80) percent of school districts 
bargain with administrators, to discover the range of attitudes toward administrator unionism. In Iowa, the majority favored formal collective bargaining believing it would enhance their leadership positions. A direct relationship was found to exist between principals' satisfaction with salaries and fringe benefits and their attitudes toward formal collective bargaining. Principals who reported below-average salaries and benefits were strongly pro-union; those reporting above-average salaries and benefits were not. Secondary principals favored formal bargaining more than elementary principals, and principals with one to five years of experience were less supportive of unions than older, more experienced colleagues.

In connecticut, principals reported bargaining had increased their participation in decision making and that they had regained some authority. They noted improved communication with the superintendent and the board, clarification of their roles in the school system, increased job security, and enhanced salaries and benefits. They also indicated bargaining favorably affected their morale (Sweeney and Rowedder, 1980).

A Nasstrom and Pier (1983) study compared bargaining and non-bargaining principals to ascertain granted employment rights and personal satisfactions with particular prerequisites of employment. A comparison was made on the basis of five contractual or related agreement rights and five 
distinct aspects of personal satisfaction. The investigation of the contractual items rested on a null hypotheses that no significant differences existed between contracts of those who bargained and those who did not. This investigation of perceptions was guided by a null hypotheses that no significant statistical difference would exist. A stratified random sample was identified based on geographical and school district population information. The null hypotheses was rejected based on the findings relative to contractual differences. No significant differences were found in attitudes.

In Pennsylvania, a state without legal mandate for collective bargaining, survey data were collected from three hundred secondary principals indicating seventeen percent (17\%) had some type of formalized procedure for presenting self interest issues to school boards. Nineteen percent (19\%) indicated some informal dialogue with their boards, while thirty percent (30\%) had informal input only with their superintendents (Caldwell, 1983). On this basis thirty (30) percent of all principals were excluded from any type of dialogue with either their school board or superintendent in matters relating to wages or working conditions. Caldwell's study design employed a survey methodology with a questionnaire format.

In a comparison study (Caldwell and Paul, 1983), an analysis of the actual agreements between middle management 
and school boards in Pennsylvania was undertaken. In ten percent $(10 \%)$ of the documents, principals were provided with specifically defined and written provisions relating to formal procedures for input into wage and fringe benefit policies. Caldwell and Paul concluded from this that many principals depend on verbal understandings and have little or no input into such decisions. These data suggest the relationships between school boards and their building managers significantly varies along a continuum ranging from active involvement of principals relative to terms of employment resulting in a definitive written agreement, to unilateral settings of personnel policies passively accepted (Caldwell and Paul, 1983). Where private and federal sectors are governed by one legal framework, public school labor relations are controlled in at least thirty one states by collective bargaining statutes (Caldwell and Paul, 1983). The structure of the bargaining relationship has been precipitated by these state statutes. The statutes governing educational collective bargaining are diverse in nature. Currently, seven of the previous thirty-one states all deny administrators collective bargaining rights.

The Pennsylvania study (Caldwell, et al, 1981) confirms earlier research findings on principals' participation in a formally defined process for determining wages and benefits as consistently enhancing organizational climate and improving principal performance. 
A study conducted in New Jersey and Pennsylvania with all building level administrators determined there was a significant relationship between the existence of collective bargaining for public school principals and their perceptions of working conditions. The study reveals principals involved in collective bargaining perceive they enjoy significant advantages over their non-bargaining counterparts (williams, 1985). This study identified nine determinants of working conditions and each of these were examined individually in an attempt to discover significant differences between the perceptions of bargaining and non-bargaining principals. Onehundred (100) principals in New Jersey and one-hundred (100) principals in Pennsylvania were surveyed with a return rate of seventy-one (71\%) percent. For analyses, mean scores were grouped and the T-test for significance was used between the two groups as well as an analysis of the variance when the three group means were studied. The results confirmed a higher degree of perceived satisfaction by principals who bargain as compared to those who did not bargain.

In another study, (Morris, 1985) the results indicated principals organized for purposes of collective bargaining realize better defined working conditions than their nonbargaining colleagues. This study was undertaken to determine if elementary principals organized for the purpose of collective bargaining possess better working conditions and enjoy greater job satisfaction when compared to those who are 
not organized for purposes of collective bargaining. Research designed instruments were administered to two-hundred ninetyseven (297) non-union and two-hundred fifty-four (254) union, randomly selected, elementary principals. Chi-square and Ttests of significance were applied to the data collected. Collective bargaining did not insure greater job satisfaction, improved conditions of work or greater control of the principals job responsibilities.

In a Minnesota study comparing bargaining and nonbargaining principals, bargaining constituted a major vehicle in the granting of rights to principals. However, the absence of these rights did not result in dissatisfaction with rights (Morris, 1985). In these investigations, controls such as size of district and level of administration (secondary or elementary) were considered and found to have no significant impact on the findings (Nasstrom and Pier, 1983).

The Morris (1985) and Williams (1985) studies illustrate the uncertainty surrounding an individual's perceptual versus actual differences in existing working conditions. Principal's collective bargaining represents a major alteration in the power structure of American education. The findings are inconsistent about whether perceptual differences of working conditions exist between principals who bargain and principals who do not. There is imited information on principals' collective bargaining. This study is a further investigation into principals' perceptions of their working 
conditions and the comparison of principals who are able to participate in the collective bargaining process to those who do not collectively bargain due to statutory limitations.

\section{SUMMARY}

In this chapter, a review of organizational theory introduced concepts and a historical overview of collective bargaining was presented. The specific studies pointed to the lack of certainty regarding the influence of collective bargaining on principals' perceptions of their working conditions. The studies also suggest a need for more information in this area.

In Chapter III, the research methodology and procedures selected for the conduct of the research study will be introduced and reviewed. This chapter includes a review of the (1) research model, (2) research methodology, and (3) procedures specific to the study. It also includes a discussion of the research instrument, population, data collection procedures, and the data analysis techniques selected for the study. 
CHAPTER III

\section{RESEARCH METHODOLOGY \\ AND PROCEDURE}

\section{INTRODUCTION}

This chapter presents the research methodology and procedures selected to conduct the study. The presentation includes a review of the (1) research model, (2) research methodology, and (3) procedures specific to the study including a discussion of the (a) population and study sample, (b) data collection procedures (c) research instrument, and (d) the data analysis activities selected for the study.

THE RESEARCH DESIGN

The design for this study is quantitative in nature. The research model was developed from the literature review presented in Chapter II. These scholarly contributions and research studies, which cite collective bargaining's impact upon the perceptions of principals regarding working conditions, were used to design a framework for this research. (See Figure 3). 


\section{RESEARCH DESIGN}

Perceptions of Principals Regarding Forking Conditions In Washington who Can Collectively Bargain and Principals in oregon who Can Not Collectively Bargain

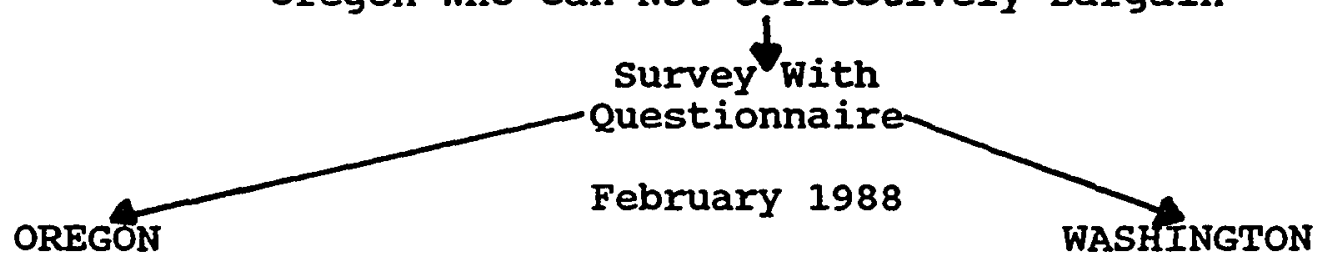

Oregon

Principals

Can Not Collectively

Bargain

Random Sample

of Principals
Washington

Principals

Can Collectively

Bargain

Random Sample of Principals

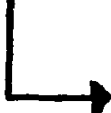

Perceptions of Working Conditions

$\rightarrow$

Compare

Significant Differences

\section{Categories}

1. Salary

2. Written Contracts

3. Autonomy

4. Power and Authority

5. Job Security

6. Fringe Benefits

7. Role Definitions

8. Communication

9. Decision-making

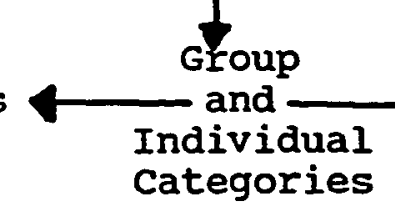

Perceptions of Working Conditions

\section{Categories}

1. Salary

2. Written Contracts

3. Autonomy

4. Power and Authority

5. Job Security

6. Fringe Benefits

7. Role Definitions

8. Communication

9. Decision making

Figure 3. Diagram of research study design.

\section{RESEARCH METHODOLOGY}

The research method used in gathering and analyzing the data was descriptive in nature. Descriptive research "describes and interprets what is. It is concerned with conditions or relationships that exist; practices that 
prevail; beliefs, points of view or attitudes that are held; processes that are going on; or trends that are developing" (Best, 1986, pg. 79). This investigation utilizes a specific subcategory of descriptive research known as the self-report survey .

Survey research is a useful tool in education. It is ideally suited to and best adapted to the study of personal and social facts, beliefs, and attitudes (Kerlinger, 1973). Survey research has two basic advantages: 1) it has a wide scope and can deal with a great deal of information from a large population and 2) is accurate (Kerlinger, 1973). According to Babbie (1973), survey research is (1) logical and facilitates logical understanding; (2) deterministic, as it clarifies cause and affect, (3) general, because its purpose is to understand a large population and the generalizability of the findings to be tested and retested, (4) parsimonious, as a variety of explanatory models can be constructed and the best one selected for use, and (5) specific, based on definitions and measurements (Babbie, 1973).

Best and Kahn (1986) note surveys as one of the most commonly used research methods in the study of individuals. This method gathers data from a relatively large number of cases at a particular time. The survey method is not concerned with characteristics of individuals, but rather is concerned with the generalized statistics which result when data are abstracted from a number of individual cases. The 
use of questionnaires mailed to school administrators has proven successful in prior studies comparing bargaining and non-bargaining principals. Nasstrom and Pier (1983) compared bargaining and non-bargaining principals in Minnesota both in employment rights and personal satisfaction with employment. Their study includes questionnaires mailed to principals to determine their perceptions regarding the bargaining process. Caldwell and Paul (1982) used a survey of three-hundred (300) principals in Pennsylvania and their inclusion in formal or informal associations with school boards. Morris (1985) employed the survey technique to determine if elementary principals organized for purposes of collective bargaining possessed a greater number of working conditions and enjoyed greater job satisfaction when compared to elementary principals not organized for these same purposes. Williams (1985) surveyed two-hundred (200) principals in Pennsylvania and New Jersey to determine the relationship between the existence of collective bargaining for school principals and their perceptions of working conditions.

The present study is similar to Nasstrom and Pier's and William's in its focus on comparing bargaining and nonbargaining principals. However, the present study examines only the principals' perceptions of their working conditions in two states, one which legislatively permits school principals to collectively bargain and one which does not. The determinants of principals' working conditions were 
identified and each of these were examined individually for significant differences between the perceptions of bargaining and non-bargaining principals. This design is diagrammed in Figure 4 .

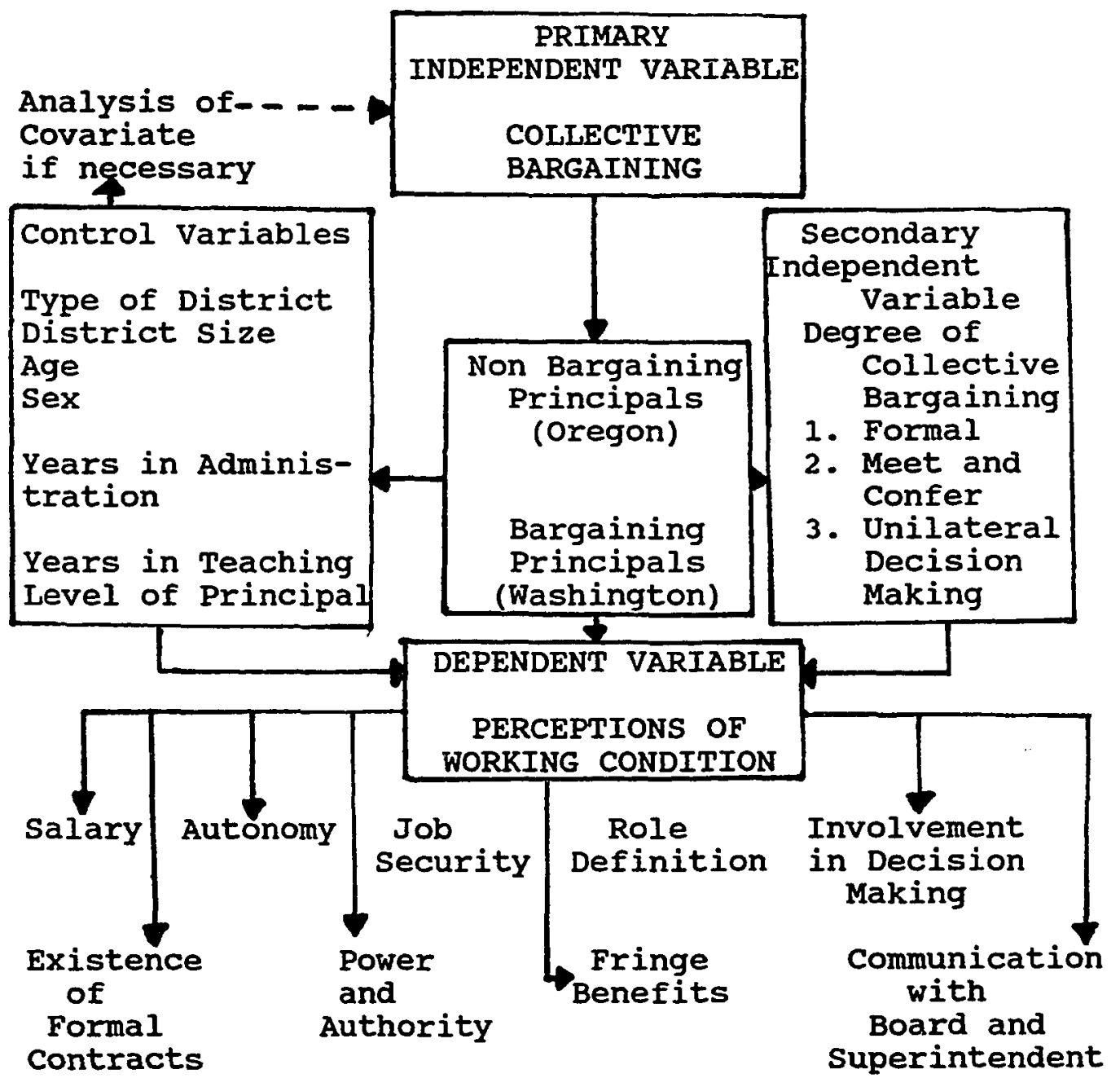

Figure 4. A schematic diagram of the research model. 
RESEARCH QUESTION

As stated previously, washington school principals may establish wages, hours and other conditions of employment through collective negotiations with their superintendents and school boards. Oregon laws do not sanction this arrangement.

The primary major research question addressed in this study was:

Does the existence of collective bargaining have an impact on public school principals' perceptions of their determinant areas of working conditions?

\section{HYPOTHESES}

Simply stated the null hypothesis assumes there is no significant difference in the perceptions of working conditions by bargaining principals as compared to nonbargaining principals.

This analysis includes nine sub-hypotheses:

1. There is no significant difference in the perceptions of bargaining principals as compared to non-bargaining principals regarding salary.

2. There is no significant difference in the perceptions of bargaining and non bargaining principals relative to the existence of formal written contracts.

3. There is no significant difference in the perceptions of bargaining and non-bargaining principals relative to 
autonomy.

4. There is no significant difference in the perceptions of bargaining principals as compared to non-bargaining principals relative to power and authority.

5. There is no significant difference in the perceptions of job security between bargaining and non-bargaining principals relative to job security.

6. There is no significant difference in the perceptions between bargaining and non-bargaining principals relative to fringe benefits.

7. There is no significant difference in the perceptions between bargaining and non-bargaining principals relative to role definition.

8. There is no significant difference in the perceptions between bargaining and non-bargaining principals in the level of communication with school boards and superintendents.

9. There is no significant difference in the perceptions between bargaining and non-bargaining principals relative to their involvement in decision making.

A second research question was additionally analyzed in this study:

Does the level of collective bargaining have an effect on the perceptions of principals with regard to the nine areas of working conditions?

This second research hypothesis investigated the level 
of collective bargaining and the perceptions of the working conditions of public school principals. Nine additional subhypotheses probed the secondary issue:

1. There is no significant difference of the three levels of collective bargaining relative to the perception of salary.

2. There is no significant difference of the three levels of collective bargaining relative to the perception of the existence of formal written contracts. 3. There is no significant difference of the three levels of collective bargaining relative to the perception of autonomy.

4. There is no significant difference of the three levels of collective bargaining relative to the perception of power and authority.

5. There is no significant difference of the three levels of collective bargaining relative to the perception of job security.

6. There is no significant difference of the three levels of collective bargaining relative to the perception of fringe benefits.

7. There is no significant difference of the three levels of collective bargaining relative to the perception of role definition.

8. There is no significant difference of the three levels of collective bargaining relative to the 
perception of the level of communication with school board and superintendent.

9. There is no significant difference of the three levels of collective bargaining relative to the perception of involvement in decision making.

CONTROL VARIABLES

A third research question was developed to control for certain demographic variances in the sample population:

Is there a significant difference between bargaining non bargaining principals in each of the demographic factors?

This analysis included seven sub-hypotheses:

1. There is no significant difference between bargaining and non-bargaining principals' perceptions relative to type of school district.

2. There is no significant difference between bargaining and non-bargaining principals' perceptions relative to district size.

3. There is no significant difference between bargaining and non-bargaining principals' perceptions relative to age.

4. There is no significant difference between bargaining and non-bargaining principals' perceptions relative to their sex.

5. There is no significance between bargaining and non- 
bargaining principals' perceptions relative to their years in administration.

6. There is no significant difference between bargaining and non-bargaining principals' perceptions relative to their years in teaching.

7. There is no significance between bargaining and nonbargaining principals' perceptions relative to their level of principalship.

These control variables were analyzed with regard only to the two states to compare the samples of the population for any significant differences.

\section{THE POPUIATION AND STUDY SAMPLE}

The population for this study consists of all elementary and secondary public school principals in the states of oregon and Washington who serve in the role of building principal and not superintendent. Principals who also serve as superintendent in their districts were excluded from the population.

There are nine hundred eight (908) school principals in the state of oregon who serve solely as principal and one thousand one hundred two (1102) in the state of Washington.

In populations this large, there is no need to obtain information from all individuals. A variation of the random sample technique was selected for use in this study. This variation is called simple random sampling technique (Issac 
and william, 1983). This variation allows drawing from a list of potential respondents on an ordered basis.

Lists of all school principals in oregon were obtained from the oregon state Department of Education and from the Superintendents office of Public Instruction in Washington. These lists provided a complete and up to date list of school principals in both states.

Before the lists could be used for respondent selection, it was be necessary to identify any principal who also served as the superintendent of a school district, due to the size of the school district. These individuals were excluded due to a perceived lack of role definition in the area of labor management relations. This factor might influence responses from superintendent/principals if selected. The principals on the lists were then numbered sequentially by state.

A group of one hundred (100) principals were selected from the oregon list (eleven percent) as respondents using a table of random numbers and a group of one hundred (100) from the Washington list (nine percent) using a table of random numbers.

The use of a stratafied random sampling technique insured the samples were representative of the total populations of principals in the two states. A sample size of ten percent $( \pm 10 \%)$ constitutes the actual group for this investigation. 


\section{SAMPLING PROCEDURE}

In order to insure the sample was representative of all school principals a random sample procedure was used. To produce an unbiased sample, a list of all principals was obtained from each state department of education and numbered consecutively, excluding names of those who also served as superintendents of the district. Using a computerized random numbers chart for each list, the sample of one hundred principals from each state was selected.

This sample size represents approximately ten percent of the total population available for study. According to Ary (1985), sample size depends upon the precision the researcher desires in estimating the population parameter at a particular confidence level (Ary et al, 1985). There is no single rule used to determine sample size. This researcher determined two hundred (200) principals or ten percent of the total population was of sufficient size to be representative of the total study population.

\section{PROCEDURES}

In February, 1988 the questionnaire was mailed by U.S. Mail to each of the two hundred selected principals in oregon and Washington.

Each questionnaire contained a cover letter summarizing the research and outlining the effort necessary for its 
completion (see Appendix A) and a letter of support from the Director of the Association of Washington School Principals. Enclosed with the questionnaire was a postage paid return envelope and a Baskin and Robbins Ice Cream Gift certificate as a "reward" to each participating principal. The ice cream certificates were to increase the rate of return and reach the goal of an $80 \%$ return rate. Each cover letter and questionnaire included a code which allowed the researcher to monitor which respondants returned the survey. The cover letter, letter of support and questionnaire appear in the appendix. The questionnaire was designed to take fifteen minutes to complete. Respondents were requested to return the questionnaire within two weeks after receipt. After a followup letter was sent which had limited response, a seventy four (74) percent return rate was achieved for the study. The return rate for oregon was sixty seven (67\%) percent and eighty $(80 \%)$ percent for Washington. The original letter and follow-up letter are contained in the Appendix A.

\section{INSTRUMENTATION}

The instrument selected for data gathering for the study is the School Principals' Working conditions Questionnaire. This instrument, developed by the researcher, was developed from a combination of the Middle Management Working Conditions Questionnaire developed by Williams (1985), and The Principal Attitude Questionnaire...Non-Union and The Principal Attitude 
Questionnaire...Union by Morris (1985). The questionnaires from which the study instrument was developed have been used in similar studies measuring the perceptions of school administrators regarding working conditions for the purpose of answering questions on the process of collective bargaining. Nine areas of concern to school principals as noted by williams (1985) are identified as the determinants of principal's working conditions. The areas to be measured: salary, existence of formal written contracts, autonomy, power and authority, job security, fringe benefits, role definitions, communication and involvement in decision making are included.

In Williams (1985) study of principals' perceptions regarding working conditions these determinants were used and for any possible comparison to prior study results it would be beneficial to use the same determinants. The two instruments from the prior studies were found to be valid and reliable measures of principal's perceptions in specific studies conducted by the researchers related to collective bargaining (Morris, 1985 and williams, 1985). In addition to the information combined from the prior two investigations, eight questions were added to the proposed study's instrumentation to even the balance of questions in each determinant area.

Thirty-two questions collected data specific to the dependent variables of the research design on working 
conditions. Nine dependent variable subsets were identified: 1) salary, 2) existence of formal written contracts, 3) autonomy, 4) power and authority, 5) job security, 6) fringe benefits, 7) role definitions, 8) communication and 9) involvement in decision making to collect subcategory data relative to the perceptions of the respondent principals. Each of the thirty-two (32) items made a statement about the management of schools. Respondents were instructed to indicate the extent to which the stated condition actually exists in their school district based on a Likert-type scale. The scale ranged from a high of 5 - (To a very large extent) to a low of 1 - (Not at all). There were three to five items devoted to each of the nine areas designated as of primary concern to school principals (Williams, 1985). (See Figure 5).

Anonymity of the respondents was guaranteed. Special instructions were provided to those who desire to receive a copy of the results; a stamped, self addressed envelope was included for the instrument's return and a Baskin Robbins ice cream certificate as a "Thank You" for their completion and participation in the study.

Due to the lack of specific measures listed in the research for previous instruments this instrument was checked for reliability through a test - retest model and a split half reliability check.

The test-retest reliability tests consistency of a 
subject score over time (Ary et al, 1985). In the test retest procedure, the instrument was administered to twenty (20) principals, twice, with a two week time interval between each administration. The reliability for the instrument using Pearson's $R$ correlation was .96 reliability in the test retest procedure.

\begin{tabular}{ll} 
& $\begin{array}{l}\text { Reliability } \\
\text { of Question } \\
\text { Determinant Area } \\
\text { Set } \\
\text { (Test-Retest) }\end{array}$ \\
\hline
\end{tabular}

1. Salary

$* 12, * 13, * 23 \quad .92$

2. Existence of Formal Contracts

$\star 16, * 18, * * 22 \quad .97$

3. Autonomy

4. Power and Authority

$* 29, * 30, * * 31 \quad .95$

5. Job Security

6. Fringe Benefits

$* 19, * 20, * * 21, \quad .91$

$* * 28$

$* 11, * 17, * * 32 \quad .100$

$\star 4, * 14, * 15, \quad .97$

7. Role Definition

8. Communication

9. Involvement in Decision Making

$\star * 27$

$\star 10, * 22, * 24 \quad .89$

$\star 1, * 2, * 3, * * 25, \quad .96$

$* * 26$

*5, $* 6, * 7, * 8, \quad .99$

* other research

** researcher constructed

Figure 5. Nine determinant area question distribution.

The split - half technique is one of the most popular reliability checks (Ary, 1985). The split - half reliability for the instrument was .96 using Pearson's $R$ and .99 using the Spearman - Brown Prophecy formula to compensate for the fact that reliability was estimated from a test one-half the length of the final form. 
Content validity cannot be expressed in numerical terms. It is the validation of the content based essentially, and out of necessity, on judgement. It involves the careful and critical examination of the test items as they relate to the specified content area (Ary, et al 1985).

Validity of the instrument was checked in two ways. A ten member panel of principals who were not in the respondent group was selected to review and critique the instrumentation format and questionnaire content reliability. These principals were known to the researcher, and it was believed they would be objective and candid in review of the questionnaire instrument. All ten members reviewed the instrument, with one member indicating need for specific clarification. This clarification, in the demographic information, was regarding his district's classification as "urban, rural or suburban". As a result the classification of "small town" was added.

The second check for validity was a review and critique by academic faculty at Portland state University. Those faculty members assisting with the final revision of the instrument were Dr. Joel Arick, an educational research specialist, Dr. Kathleen Westbrook, Assistant Professor of Education, Dr. John F. Heflin, Associate Professor of Education, Dr. Jack Lind, Professor of Education and Dr. Nancy Koroloff, Professor of Social Work. Additional assistance was provided by Tom Moreno, a statistician and research 
methodologist.

The research instrument was designed and developed between March 1987 and February 1988, under the direction of Dr. John F. Heflin, Chairperson of the investigator's Dissertation Committee and Dr. Joel Arick, a member of the investigator's Dissertation Committee.

\section{STATISTICAL ANALYSIS}

This study employs a descriptive design using survey techniques to describe two groups of principals and compare their perceptions of working conditions. The determinants of principals' working conditions as identified, are examined individually to discover the existance of any significant difference in the perceptions of working conditions for bargaining and non-bargaining principals.

After all the data was collected and organized, it was analyzed using descriptive statistics to uncover differences between the two comparison groups. The nine determinants of principals' working conditions: salary, existence of formal written contracts, autonomy, power and authority, job security, fringe benefits, role definitions, communication and involvement in decision making were examined.

\section{Primary Independent Variable Data Analysis}

Responses to the questions were compared for the two principal groups. The analysis of the data is presented in 
tabular format and compares principals' perceptions in the nine areas of primary concern to principals (see pages 50 and 51).

The items pertaining to each of the nine determinant areas of working conditions were grouped together, totaled and averages computed. For example, items \# 12, 13, and 23, which pertain to salary, were grouped together. A one-way analysis of variance was used to compare the perceptions of bargaining and non-bargaining principals for each of the nine determinant areas to determine significant differences. These data were no longer treated as ordinal but were collapsed to simulate interval data and a one-way analysis of variance procedure applied for each of the respective groups.

Secondary Independent Variable Analysis

Respondents' answers were grouped into catagories representing levels of collective bargaining including formalized collective bargaining, informal, and unilateral decisions. A one-way analysis of variance was used to compare responses to these questions by principals and allow analysis of the secondary research questions noted on pages 52 and 53 .

\section{Covariance}

Any demographic factors found to vary significantly between bargaining and non-bargaining principal groups (see demographic factor section), were used as covariates and an analysis of covariance procedure was conducted. Analysis of 
covariance helps to explain the effect of the primary independent variable (bargaining/non-bargaining) while controlling the effect of the identified demographic factors. Data were reported with respect to any variation in respondents in terms of demographic information. As an example, variation in either level of the principalship or size of school district were reported. These data were analyzed using a chi () technique to determine if significant differences between demographic variables and Oregon and Washington principals' perceptions were present. This analysis includes seven additional sub-hypotheses enumerated on pages 53 and 54 of this study.

\section{SUMMARY}

Chapter III presents the research methodology and procedures used in the conduct of this study. The information includes a review of the (1) research model, (2) research methodology, and (3) procedures specific to the study. A discussion of the population and study sample, data collection procedures, research instrumentation, and the data analysis techniques were enumerated.

Chapter IV discusses the results of the data analysis activities. 
CHAPTER IV

\section{ANALYSIS OF THE DATA}

Chapter IV is divided into five sections. The first section includes the primary analysis for the nine determinants of working conditions. The second section covers a secondary analysis of the data based on the level of collective bargaining and perceptions of working conditions as identified by the nine sub-hypothesis questions. Section three reports the demographic analysis findings which includes seven sub-hypotheses. Section four presents data from the analysis of covariance and section five summarizes the chapter.

\section{PRIMARY ANALYSIS}

Test of the Primary Hypothesis

The primary hypothesis was constructed to determine if the existence of collective bargaining has an impact on public school principals' perceptions of their working conditions. The primary hypothesis was stated as follows:

There is no significant difference in the perceptions of working conditions in bargaining principals as compared to non-bargaining principals.

This hypothesis was tested through the application of a 
one-way analysis of variance procedure on the calcusated group means of the two sample groups on nine sub-hypotheses:

1. There is no significant difference in the perceptions of bargaining principals as compared to non-bargaining principals regarding salary.

2. There is no significant difference in the perceptions of bargaining and non-bargaining principals regarding the existence of formal written contracts.

3. There is no significant difference in the perceptions of bargaining and non-bargaining principals regarding autonomy .

4. There is no significant difference in the perceptions of bargaining principals as compared to non-bargaining principals regarding power and authority.

5. There is no significant difference in the perceptions of bargaining and non bargaining principals regarding job security.

6. There is no significant difference in the perceptions of bargaining and non-bargaining principals regarding fringe benefits.

7. There is no significant difference in the perceptions of bargaining and non-bargaining principals regarding role definition.

8. There is no significant difference in the perceptions of bargaining and non-bargaining principals in the level of communications with school board members and 
superintendents.

9. There is no significant difference in the perceptions

of bargaining and non bargaining principals in their involvement in decision making.

The data for these nine research sub-hypotheses are reported here (see Table I).

The data reported in Table I shows only two of the nine primary sub-hypotheses, the areas of Formal contracts and Autonomy, were found to be statistically significant. The remaining null hypotheses were not found to be statistically significant at $p=<.05$ level and failed to be rejected.

\section{The Existence of Formal Written Contracts}

One of the primary concerns of principals, in determining perceptions of working conditions, is the existence of formal written administrative contracts (Barea, 1978). Principals in both oregon and Washington were polled to determine the extent of written contracts.

Figure 6 shows the distribution of responses of principals who may bargain (Washington) and those who may not (Oregon). This figure shows Washington principals have a higher mean score than oregon principals with regard to the existence of formal contracts. The shape of the distribution highlights bargaining principals perceive formal written contracts exist to a greater degree than do non-bargaining 
TABLE I

LEVELS OF SIGNIFICANCE AS DETERMINED BY A ONE-WAY ANALYSIS OF VARIANCE ON THE NINE SUB-HYPOTHESES QUESTIONS REGARDING BARGAINING AND NON-BARGAINING PRINCIPALS AND THEIR PERCEPTIONS OF WORKING CONDITIONS.

\begin{tabular}{llllll} 
Working & F- & \multicolumn{3}{c}{ Significance } & \\
Conditions & Ratio & Level & & Means \\
& & P $<.05$ & DF & WA/OR \\
\hline 1. Salary & 0.027 & NS & 1,142 & \\
2. Formal Contract & 6.122 & .015 & 1,140 & $3.38 / 3.13$ \\
3. Autonomy & 7.934 & .006 & 1,140 & $2.90 / 3.24$ \\
4. Power/Authority & 0.368 & NS & 1,130 & \\
5. Job Security & 0.170 & NS & 1,128 & \\
6. Fringe Benefits & 0.181 & NS & 1,142 & \\
7. Role Definition & 0.095 & NS & 1,140 & \\
8. Communication & 0.162 & NS & 1,133 & \\
9. Decision Making & 1.977 & NS & 1,139 &
\end{tabular}

NS $=$ Not Significant

WA = Washington (Bargaining)

$\mathrm{OR}=$ Oregon (Non-bargaining)

See Appendix $C$ for additional analysis of variance statistics. 


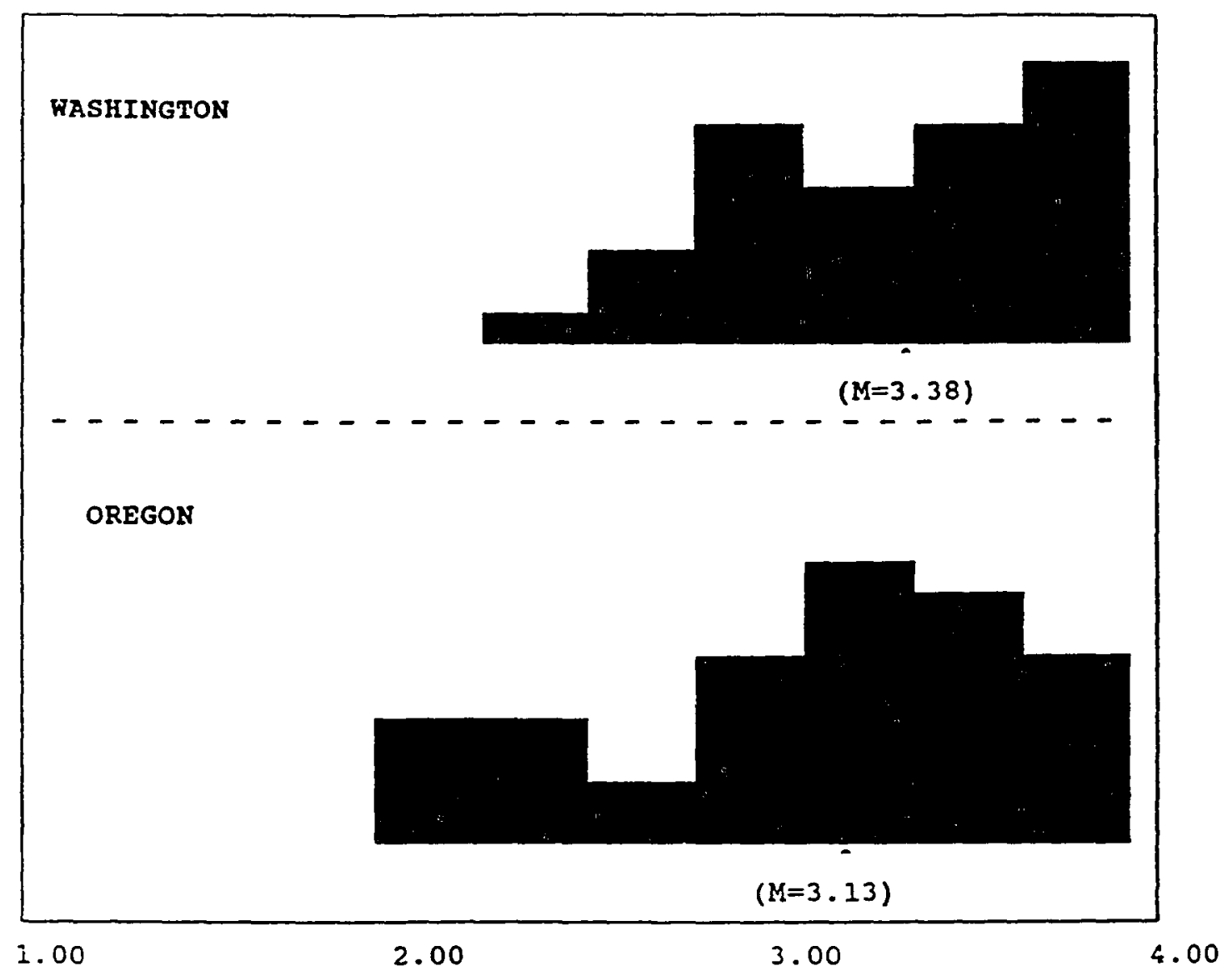

Figure 6. Histogram of principals perceptions regarding the existence of formal written contracts.

principals, whose responses were clustered at the low end of the scale.

A one-way analysis of variance of these responses was found to be statistically significantly different at .015 (See Table I).

The null form for this sub-hypothesis stated there is no significant difference in the perceptions of bargaining and non bargaining principals regarding the existence of formal 
written contracts. A test of statistical significance at the .05 level was performed and the null hypothesis was rejected (see Figure 6).

\section{Autonomy}

Another condition which was identified as having impact upon principals' perceptiond of working conditions was the degree of administrative autonomy. Independence and the discretion to manage a building were considered crucial if principals are to fulfill leadership roles.

Principals from both bargaining and non-bargaining samples were questioned about the degree of autonomy they felt they possessed. Figure 7 presents the frequency distributions of the principals' responses. The figure shows oregon principals (non-bargaining) report a higher mean score than Washington principals (bargaining) with regard to autonomy. The shape of the distribution shows non-bargaining principals perceive they have greater autonomy than do bargaining principals. Non-bargaining principals' responses were clustered at the higher end of the scale, while bargaining principals' responses spread along the continuum.

An analysis of variance procedure determining differences between the two groups was found to be statistically significant. The differences were found to be statistically significant at the .05 level (see Table I). 


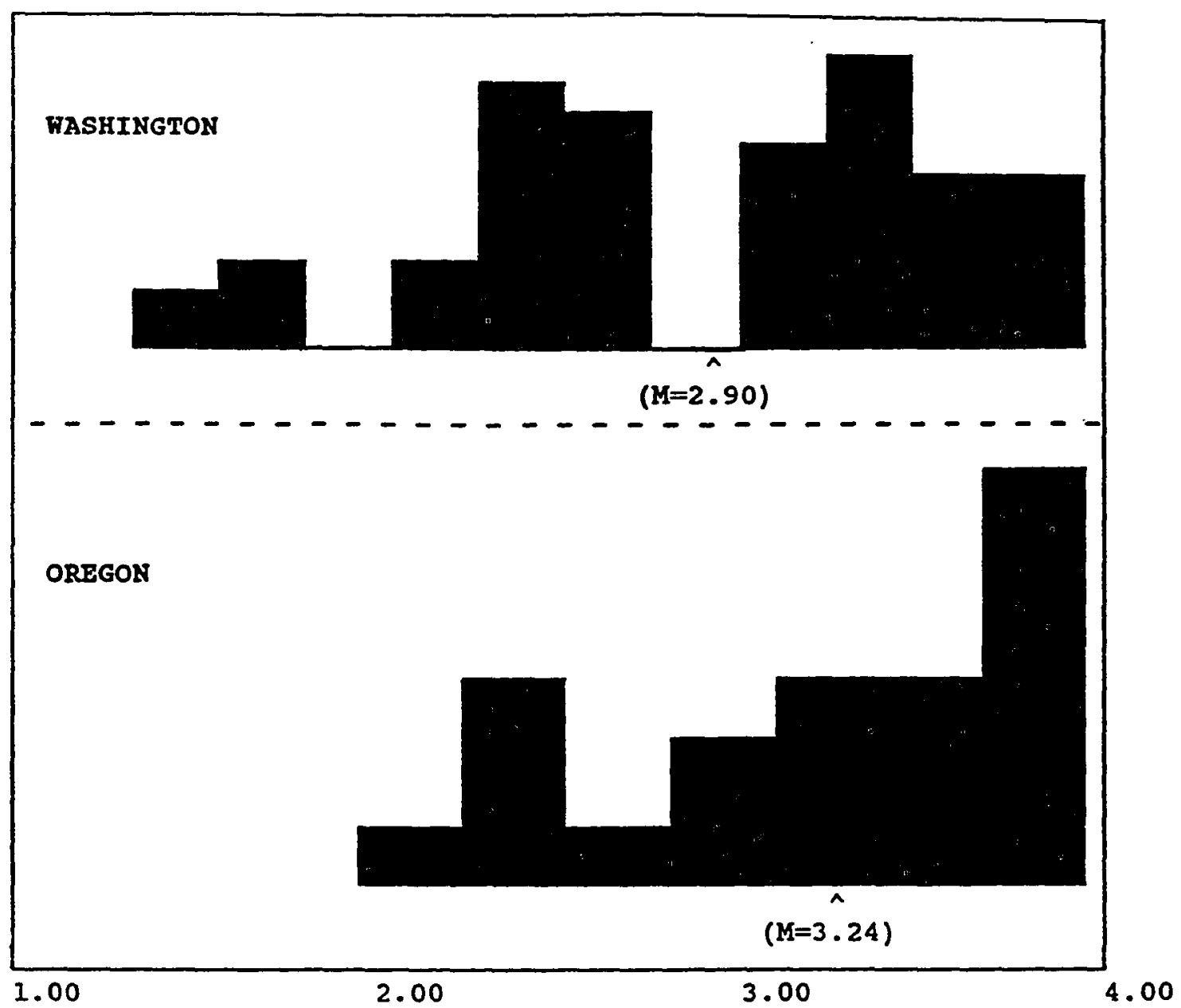

Figure 7. Histogram of principals' perceptions regarding autonomy.

The null form for this sub-hypothesis states there is no significant difference in the perceptions of autonomy of bargaining and non-bargaining principals. Based upon the selected .05 level of significance, the null hypothesis was rejected. It appears oregon (non-bargaining) principals perceive the existence of autonomy more positively than do Washington (bargaining) principals. 


\section{SECONDARY ANALYSIS}

The secondary question was to analyze for effect of three perceived levels of collective bargaining relative to principals' perceptions of the nine areas of working conditions. The levels of bargaining to which principals responded were: 1) Formal collective bargaining, 2) Informal collective bargaining and 3) Unilateral decision making(see Table II). One hundred questionnaires were sent to principals in Oregon, and sixty-seven (67) were returned. of these, eight (8) or twelve (12\%) percent were from principals who did not meet at all with representatives of top management to determine their working conditions. The school board and superintendent made these decisions and informed principals who accept these unilateral decisions.

TABLE II

LEVELS OF BARGAINING INDICATED BY PRINCIPALS' RESPONSES.

\begin{tabular}{lllll}
\hline & $\begin{array}{l}\text { Formal } \\
\text { Barg. }\end{array}$ & $\begin{array}{l}\text { Informal } \\
\text { Barg. }\end{array}$ & $\begin{array}{l}\text { Unilateral } \\
\text { Decision }\end{array}$ & $\begin{array}{l}\text { Non } \\
\text { Response }\end{array}$ \\
\hline & Num/Per & Num/Per & Num/Per & Num/Per \\
\hline Oregon & $17 / 27 \%$ & $38 / 60 \%$ & $8 / 12 \%$ & $33 / 33 \%$ \\
Washington & $22 / 30 \%$ & $39 / 53 \%$ & $12 / 16 \%$ & $20 / 20 \%$ \\
Total & $39 / 29 \%$ & $77 / 59 \%$ & $20 / 14 \%$ & \\
\hline $\begin{array}{l}\text { Num }=\text { Number } \\
\text { Per }=\text { Percent }\end{array}$ & & & & \\
\hline
\end{tabular}


Thirty-eight (38) principals reported they held informal collective bargaining meetings with the superintendent and/or representatives of the school board. This number represents sixty (60\%) percent of Oregon's respondents.

Seventeen (17) Oregon principals or twenty-seven (27\%) percent indicated that there was formal collective bargaining between representatives of middle management and the school board.

Washington principals' responses were not substantively different from the Oregon sample relative to the degree of administrative collective bargaining (see Table II). This finding was unanticipated by the researcher. Inspection of the data indicated only three $(3 \%)$ percent more Washington principals when compared to oregon principals were invoived in collective negotiations even though the statutory authority for bargaining exists in Washington state.

of the eighty (80) questionnaires returned, twenty-two (22), or thirty $(30 \%)$ percent of the Washington respondents stated they were involved in formal collective bargaining with their school boards. Thirty-nine (39), or fifty-three (53\%) percent were engaged in informal collective bargaining. There were twelve (12) principals or sixteen (16\%) percent who reported they did not meet and accepted unilateral decisions by top management concerning working conditions.

In combining data from both states, thirty-nine (39) or twenty-nine (29\%) percent of the principals perceived they 
are involved in formal collective bargaining, seventy-seven (77) or fifty-nine (59\%) percent, in informal bargaining and twenty (20) or fourteen (14\%) percent in unilateral decision processes (See Table II).

Nine sub-hypotheses were tested using a one-way analysis of variance procedure to compare responses reported by the principals:

1. There is no significant difference in the three levels of collective bargaining relative to the perception of salary.

2. There is no significant difference in the three levels of collective bargaining relative to the perception of the existence of formal written contracts. 3. There is no significant difference in the three levels of collective bargaining relative to the perception of autonomy.

4. There is no significant difference in the three levels of collective bargaining relative to the perception of power and authority.

5. There is no significant difference in the three levels of collective bargaining relative to the perception of job security.

6. There is no significant difference in the three levels of collective bargaining relative to the perception of fringe benefits. 
7. There is no significant difference in the three levels of collective bargaining relative to the perception of role definition.

8. There is no significant difference in the three levels of collective bargaining relative to the perception of the level of communication with the school board and superintendent.

9. There is no significant difference in the three levels of collective bargaining relative to the perception of involvement in decision making.

Graphic data to test these nine sub-hypotheses are reported in Table III.

\section{Salary}

The first variable having an effect on principals' perceptions was salary. A comparison of the three levels of collective bargaining (formal collective bargaining, informal bargaining, and unilateral decision making) with salary was conducted using a one-way analysis of variance procedure.

The significance level in the group means was at the .00 level. Figure 8 portrays the frequency of responses for three groups of principals: 1) principals who formally bargain, 2) principals who informally bargain and 3) principals who accept unilateral decisions with regard to salary. The shape of the distribution indicates principals who formally bargain report a higher degree of satisfaction 
TABLE III

ANALYSIS OF VARIANCE ON THE NINE HYPOTHESES REGARDING LEVEL OF BARGAINING AND PRINCIPALS PERCEPTIONS OF WORKING CONDITIONS.

\begin{tabular}{|c|c|c|c|c|}
\hline $\begin{array}{l}\text { Working } \\
\text { Conditions }\end{array}$ & $\begin{array}{l}\text { F- } \\
\text { Ratio }\end{array}$ & $\mathrm{p}=<.05$ & $\begin{array}{l}\text { Means: } \\
\text { FB/IB/UD }\end{array}$ & DF \\
\hline 1. Salary & 10.969 & .00 & $3.10 / 3.01 / 2.23$ & 2,130 \\
\hline $\begin{array}{l}\text { 2. Formal } \\
\text { Contract }\end{array}$ & 0.052 & NS & & $2, \quad 129$ \\
\hline 3. Autonomy & 2.301 & NS & & $2, \quad 128$ \\
\hline $\begin{array}{l}\text { 4. Power/ } \\
\text { Authority }\end{array}$ & 3.927 & .022 & $2.55 / 2.76 / 2.29$ & 2,120 \\
\hline 5. Job Security & 4.509 & .013 & $3.05 / 3.19 / 2.65$ & 2,120 \\
\hline $\begin{array}{l}\text { 6. Fringe } \\
\text { Benefits }\end{array}$ & 4.238 & .016 & $3.06 / 3.18 / 2.33$ & 2,131 \\
\hline $\begin{array}{l}\text { 7. Role } \\
\text { Definition }\end{array}$ & 3.612 & .03 & $3.33 / 3.26 / 2.81$ & 2,129 \\
\hline 8. Communicate & 0.336 & NS & & 2,125 \\
\hline $\begin{array}{l}\text { 9. Decision } \\
\text { Making }\end{array}$ & 6.046 & .00 & $2.90 / 3.22 / 2.77$ & 2,129 \\
\hline $\begin{array}{l}\text { NS }=\text { Not Signifi } \\
\text { FB }=\text { Formal Barg } \\
\text { IB }=\text { Informal Ba } \\
\text { UD }=\text { Unilateral }\end{array}$ & $\begin{array}{l}\text { ant } \\
\text { ining } \\
\text { gaining } \\
\text { jecisions }\end{array}$ & & & \\
\hline
\end{tabular}

See Appendix $C$ for additional analysis of variance statistics. 


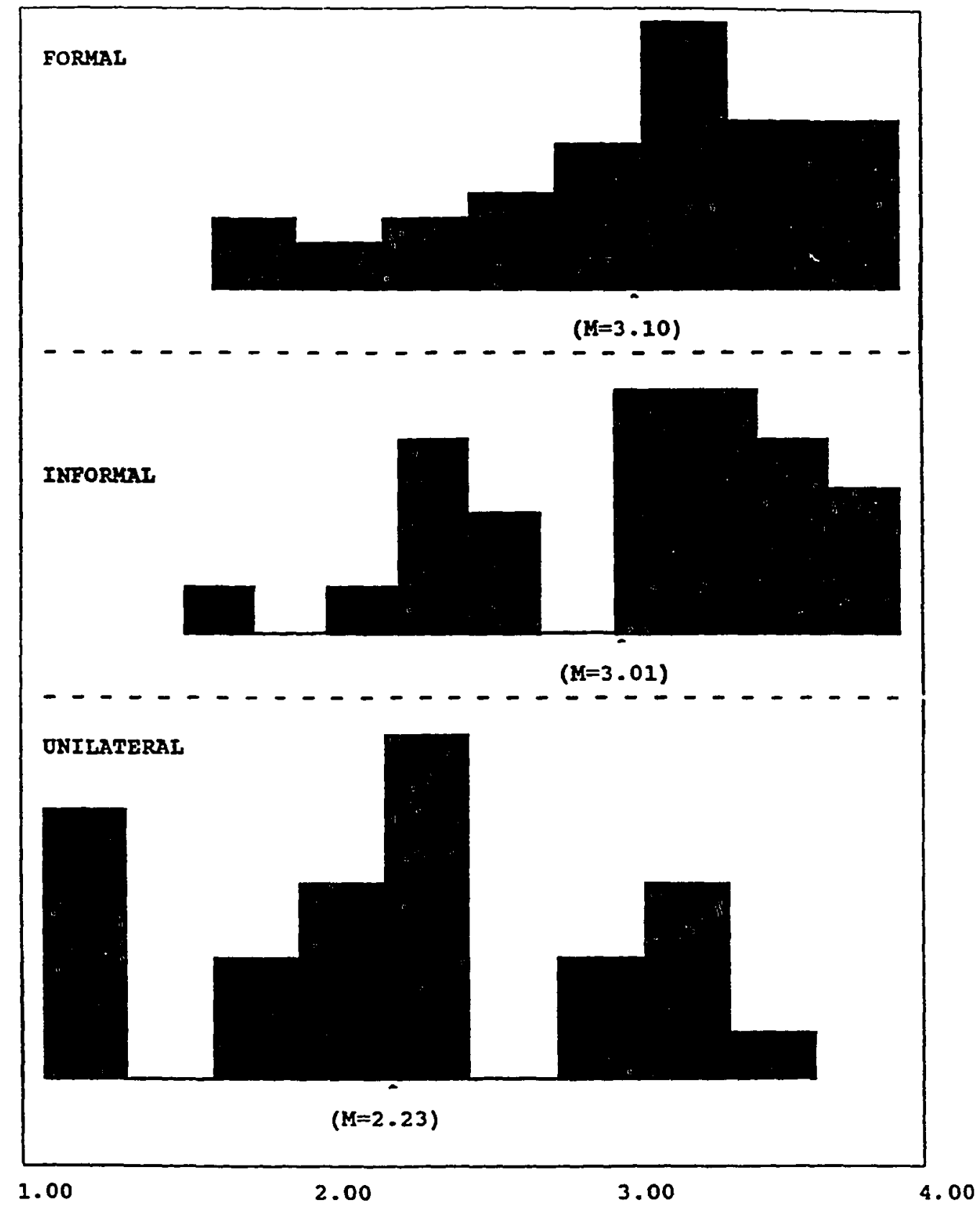

Figure 8. Histogram of principals' perceptions regarding salary and level of collective bargaining. 
with their level of salary than do principals who meet informally or those who were recipients of unilateral decisions. These responses are grouped at the higher end of the scale while the remaining groups spread more evenly over the entire continuum.

The null form of this sub-hypothesis states there is no significant difference between the three levels of bargaining relative to principals' perception of salary. A significance level of .05 level was selected. The null sub-hypothesis was rejected as the difference of the groups means was significant at the .00 level (see Table III). It appears principals who formally bargain have a higher degree of satisfaction with their salary level than reported by the other two sample groups.

\section{Power and Authority}

In comparing the levels of bargaining and principals' perceptions regarding power and authority, a one-way analysis of variance was performed.

Figure 9 depicts the frequency distribution of responses between the variable of power and authority as reported by the three sample groups. The distribution indicates the informal bargaining group had a higher mean score than the other two sample groups. These responses were clustered at two points at a higher level as compared to the other two sample groups which clustered at one point or are more 


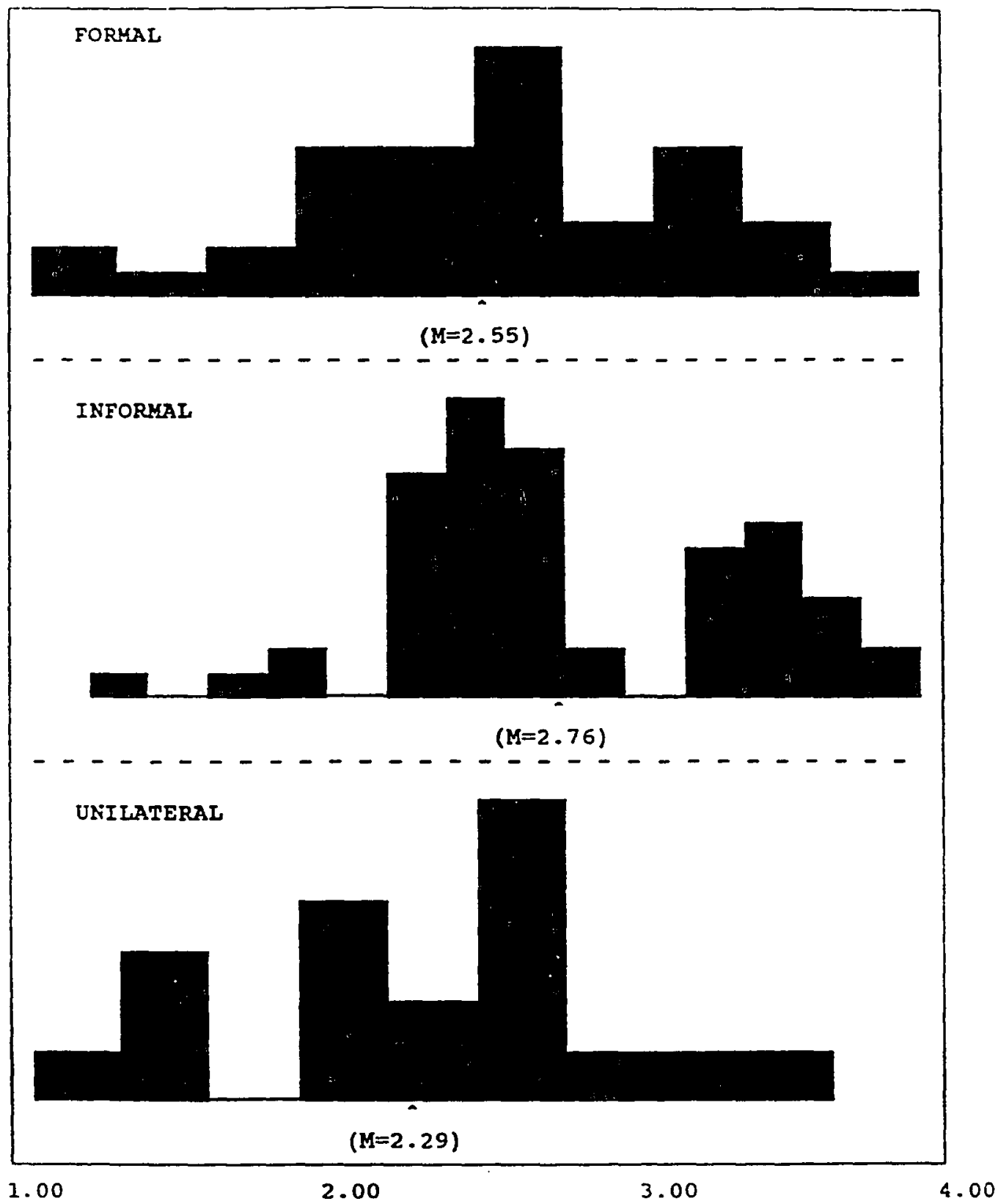

Figure 9. Histogram of principals' perceptions regarding power and authority with collective bargaining level. 
dispersed across the continuum points.

The null form of this sub-hypothesis states there is no significant difference in the level of collective bargaining relative to the perception of power and authority. When comparing the group means, a significant statistical difference at the .02 level was found and is reported in Table III. Based on a .05 rejection level, the null hypothesis was rejected and the research hypothesis retained. It appears principals who formally bargain perceive power and authority at higher levels than do the remaining two sample principal groups.

\section{Job Security}

Job security is another key factor related to working conditions. Figure 10 shows the frequency distribution of responses. Principals reported regarding their perceptions of job security and level of bargaining. The distribution shows the informal group responses clustered at the high end of the scale thereby producing a higher mean score than the remaining two principal groups. Principal responses belonging to the formal bargaining and unilateral decision groups were dispersed more broadly across the continuum.

An analysis of variance compared the means for these groups to assess significant differences. Tests of significance difference were calculated at the .01 level as noted in Table III. 


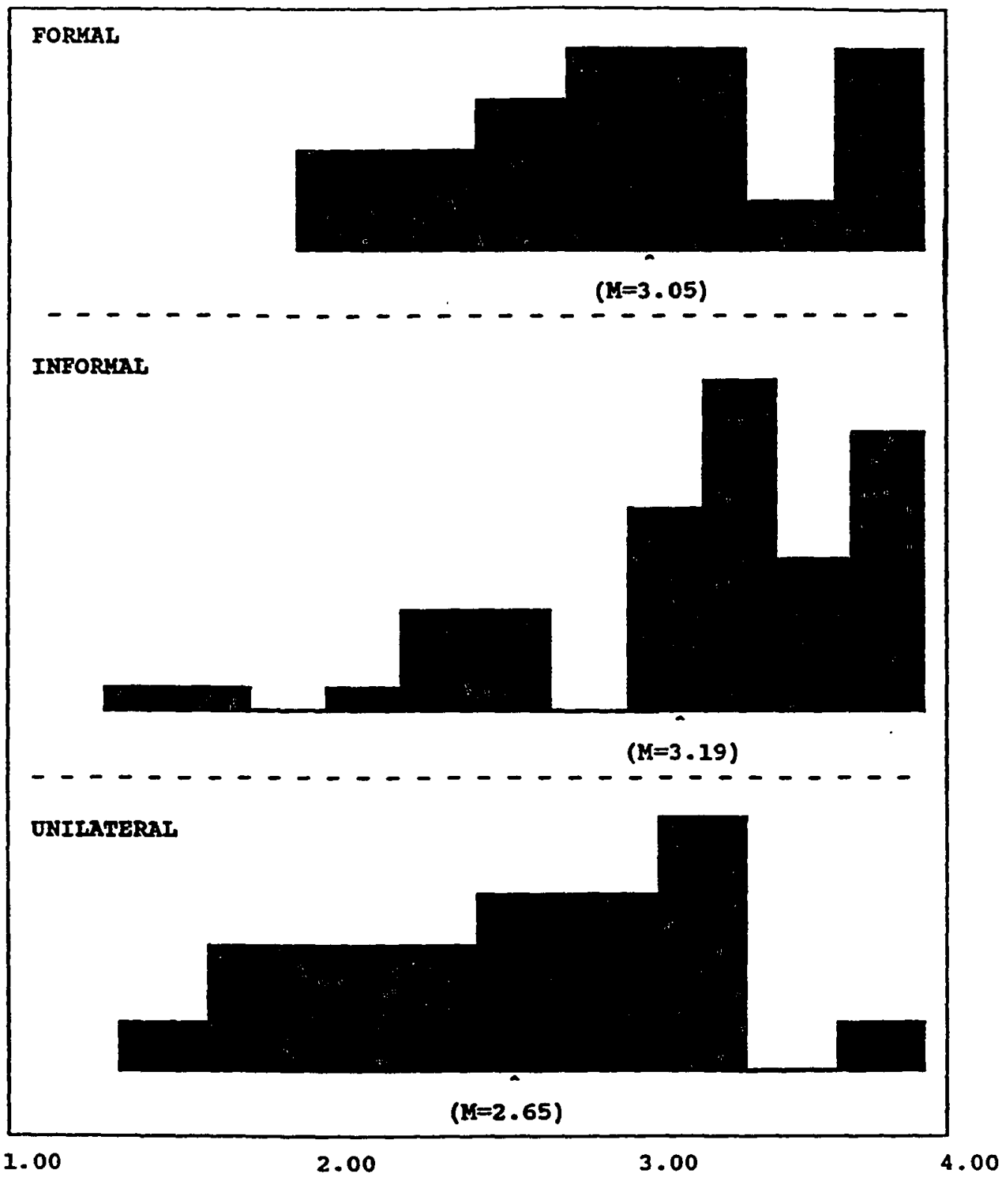

Figure 10. Histogram of principals' perceptions regarding job security with collective bargaining level. 
The null form of this sub-hypothesis states there is no significant difference of the three levels of bargaining relative to principals' perceptions of job security. Based on a statistical test at the .05 level of rejection, the null hypothesis was rejected. The data indicate principals who informally meet perceive themselves to have a higher level of job security than do principals who bargain formally or are participants in unilateral decision making (See Table III).

\section{Fringe Benefits}

Fringe benefits are another important aspect of principals' working conditions. A comparison of the level of bargaining with principals' perceptions of their fringe benefits was calculated using a one-way analysis of variance.

The means and distribution of responses for each bargaining level group are compared in Figure 11. The distribution of responses by principals in the three levels shows the informal group has a higher mean score than the other two principal groups. These responses were clustered at the high end of the continuum while the remaining two groups (formal and unilateral decision making responses) were more evenly distributed across the continuum.

The difference, as noted in Table III, shows a statistically significant difference at the .016 level, using a one-way analysis of variance. 


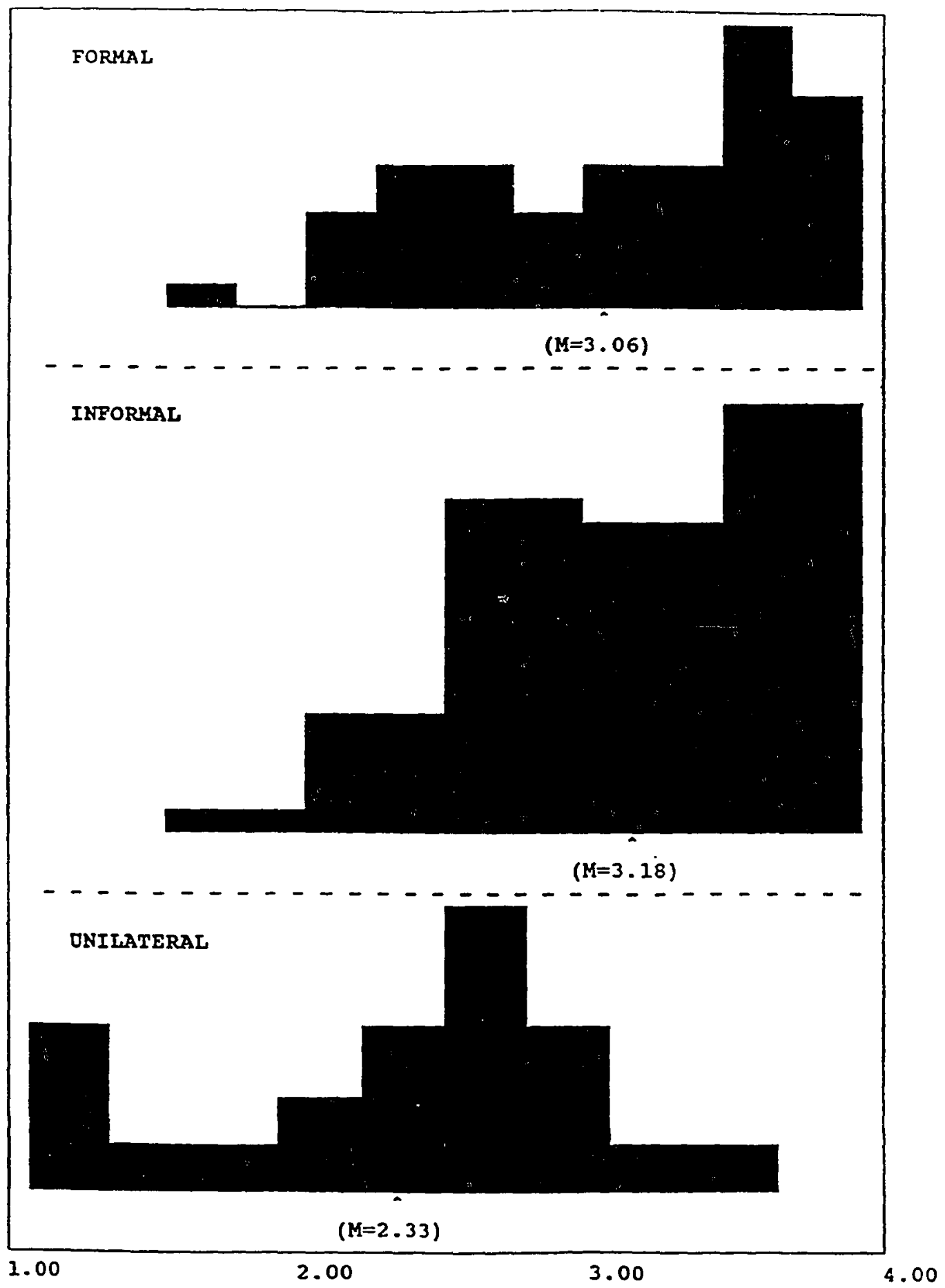

Figure 11. Histogram of principals' perceptions regarding fringe benefits with collective bargaining level. 
The null form for this sub-hypothesis states there is no significant difference amoung the three levels of bargaining in regards to principals' perceptions of fringe benefits. Based on a .05 level of rejection, the null hypothesis was rejected. There appeares to be a significant difference between those principals who informally bargain and those who formally bargain or participate in unilateral decision making. Principals who informally bargain perceive that they have a higher level of fringe benefits.

\section{Role Definition}

Role definition is defined by the elements within a job description and the related staff development programs designed specifically for administrators.

Figure 12 shows the frequency of responses of all respondent principals with regard to role definition. The distribution of responses cluster at the high end of the continuum for the formal bargaining group, reporting a higher mean score than the other two sample groups. The informal group, although also clustered near the high end of the scale, had lower overall responses and a more evenly distributed response set across the lower end of the continuum than was the case for the formal group. The responses for the unilateral group were spread evenly across the continuum.

The null form for this sub-hypothesis stated that there is no significant difference between the level of collective 


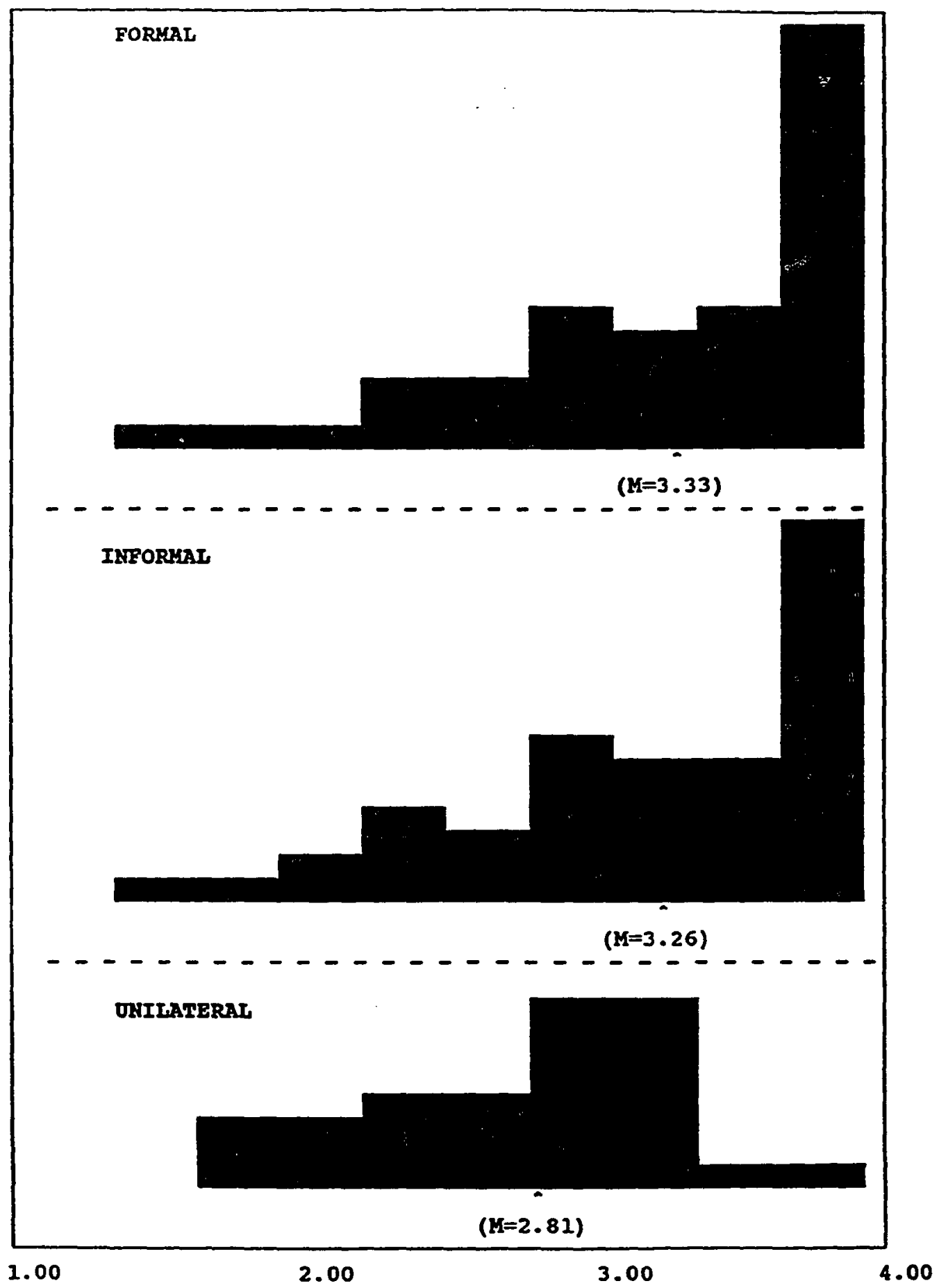

Figure 12. Histogram of principals' perceptions regarding role definition with collective bargaining level. 
bargaining and perceptions of role definition. A statistical test at the .05 level of significance led to a rejection of the null hypothesis. The difference in the means of the groups was significant at the .03 level (See Table III). There is a significant difference in the perceptions of role definition for principals who formally bargain when compared to those who informally meet or those who accept unilateral decisions.

\section{Involvement In Decision Making}

The degree of involvement in decision making was the last factor to be compared. A comparison of the level of bargaining with principals' perceptions of their participation in decision making was conducted using an analysis of variance technique.

Figure 13 shows the frequency distribution of the respondent principals who formally bargain and their perceptions of involvement in decision making as well as the responses of those principals who informally bargain and those who accept unilateral decisions. The distribution responses in the three bargaining levels shows the informal group's responses cluster toward the high end of the continuum. The mean score for this group was higher than for the remaining two groups whose responses were distributed more evenly across the continuum. 


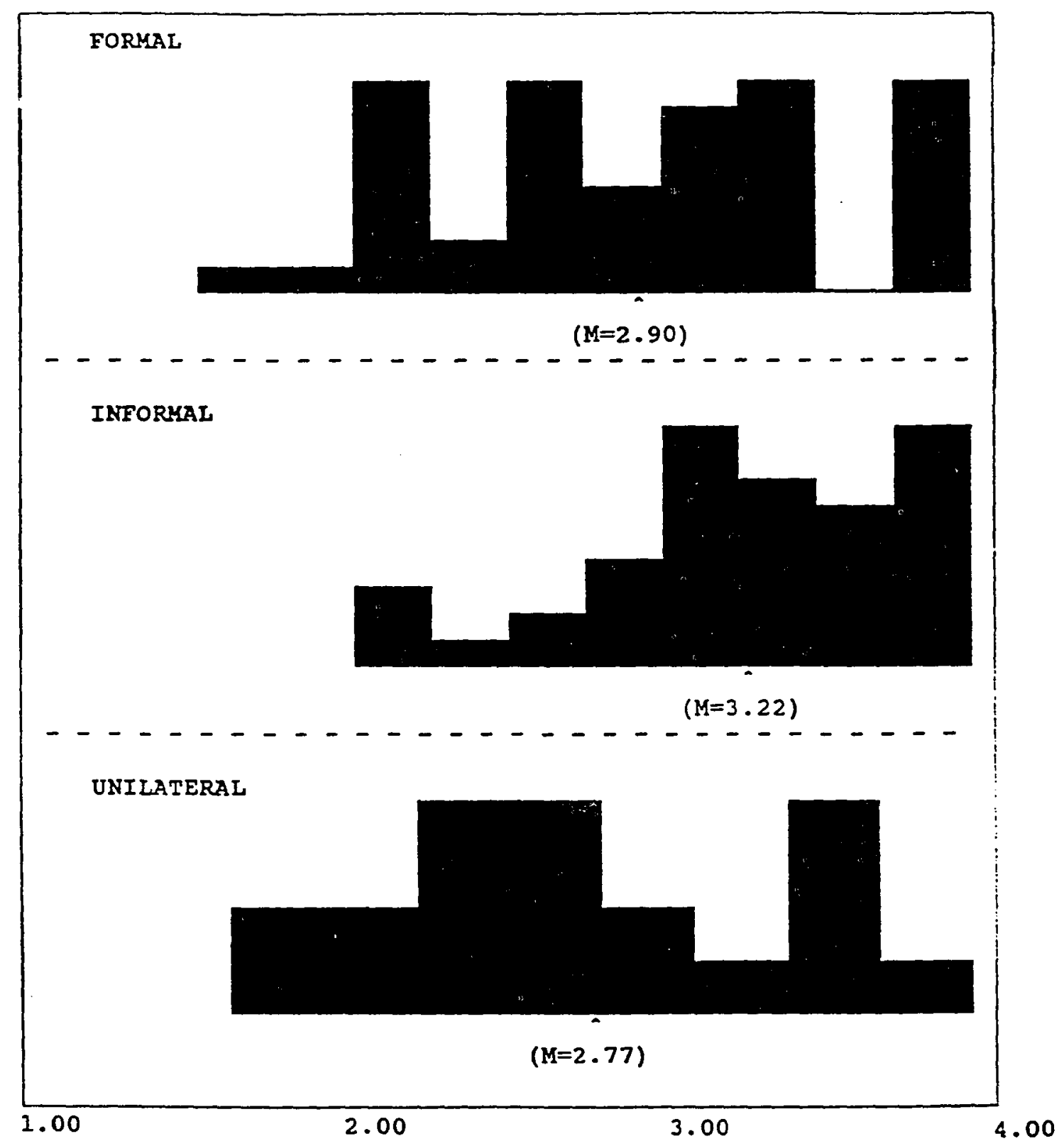

Figure 13. Histogram of principals' perceptions regarding decision making with collective bargaining level. 
The null form for this sub-hypothesis states there is no significant difference in the level of bargaining in regards to the perception of involvement in decision making. A statistical test at the .05 level led to the rejection of the null hypothesis (the difference was significant at the .00 level (see Table III)). For those principals engaging in an informal level of collective bargaining, there was a significantly higher mean score than for the other groups.

\section{DEMOGRAPHIC DATA ANALYSIS}

The third section of the data analysis activities was constructed to analyze demographic data and its possible effect on principals' perceptions of 'working conditions. The demographic variable included were: 1) district classification, 2) district size, 3) age, 4) gender, 5) years in adninistration, 6) years in teaching, and 7) current level of position. These data are reported in Table IV.

One of the hypotheses tested in this study was to determine if a significant difference exists between the two groups of principals, bargaining and non-bargaining, with each of the identified demographic variables.

This analysis included seven sub-hypotheses: 1. There is no significance between bargaining and nonbargaining principals and the type of school district. 2. There is no significance between bargaining and nonbargaining principals and their district size. 
TABLE IV

DESCRIPTION OF DEMOGRAPHIC DATA FOR THE STUDY.

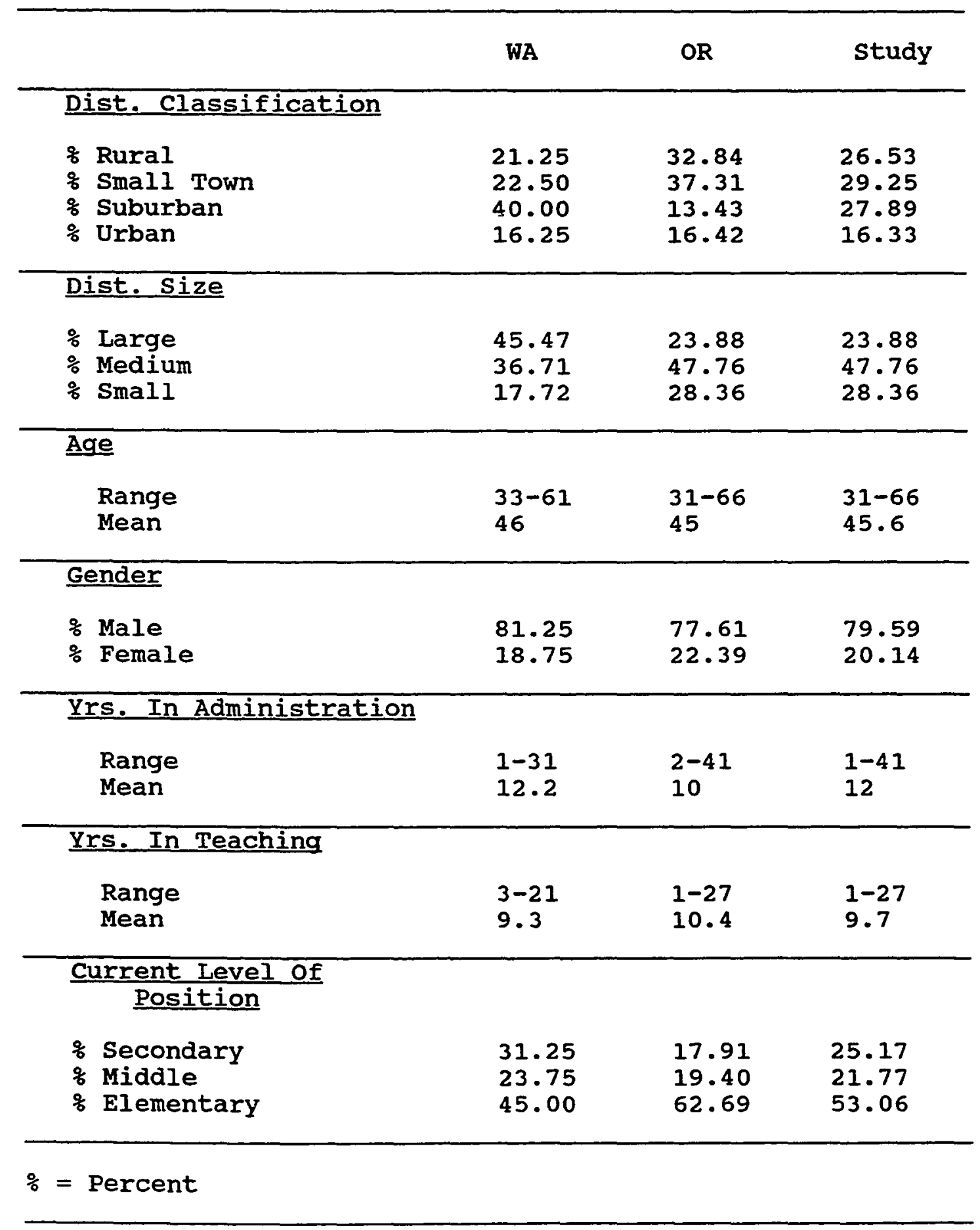


3. There is no significance between bargaining and non-bargaining principals and their age.

4. There is no significance between bargaining and non-bargaining principals and their gender.

5. There is no significance between bargaining and non-bargaining principals and their years in administration.

6. There is no significance between bargaining and non-bargaining principals and their years in teaching. 7. There is no significance between bargaining and nonbargaining principals and their level of principalship. The results of the data analysis activities using a chi Square $\left(x^{2}\right)$ analysis are reported in Table V. Seven major demographic variables were analyzed looking for major differences between bargaining (Washington) and non-bargaining (Oregon) principal groups. Two were found to be statistically significant with this analysis: district classification and district size. The other five demographic variables may be related within groups with regard to working conditions but for the analysis, the demographic variables were only considered for group the bargaining and non-bargaining bias.

\section{District Classification}

Principals responded to the district classification section of the study by classifying their district. The types of district classifications were: 1) urban, 2) suburban, 3) 
TABLE V

LEVELS OF SIGNIFICANCE AS DETERMINED BY A CHI-SQUARE ANALYSIS OF BARGAINING AND NON-BARGAINING PRINCIPAL AND THE DEMOGRAPHIC FACTOR.

\begin{tabular}{lccc}
\hline $\begin{array}{l}\text { Demographic } \\
\text { Factor }\end{array}$ & $\begin{array}{l}\text { Level of } \\
\text { Value } \\
\text { Significance } \\
\mathrm{p}=<.05\end{array}$ & DF \\
\hline 1. District Class. & 13.808 & .003 & 2,144 \\
2. District Size & 7.663 & .022 & 2,144 \\
3. Age & .297 & NS & NS \\
4. Gender & & NS & 145 \\
5. Years in Admin. & & NS & \\
6. Years in Teaching & & NS & 2,144 \\
7. Level of Position & 4.122 & & \\
\hline NS = Not Significant & & & \\
\hline
\end{tabular}

See Appendix $\mathrm{C}$ for additional analysis statistics.

small town or 4) rural (See Table VI). The significance of this variable appears attributable to a key finding that the number of principals responding from suburban districts was considerably higher from Washington than from oregon.

District classification was compared with working condition determinants found to be significant in the primary and secondary data analyses.

An analysis of variance was conducted to determine what effect district classification had on bargaining and non- 
TABLE VI

CHI SQUARE TEST OF SIGNIFICANCE COMPARING BARGAINING AND NON-BARGAINING PRINCIPALS WITH THE DEMOGRAPHIC VARIABLE OF DISTRICT CLASSIFICATION.

\begin{tabular}{|c|c|c|c|c|c|c|}
\hline & rural & small town & suburban & \multicolumn{2}{|l|}{ urban } & TOTAL \\
\hline Oregon & 14.97 & 17.01 & 6.12 & \multicolumn{2}{|l|}{7.48} & 45.58 \\
\hline Washington & 11.56 & 12.24 & 21.77 & \multicolumn{2}{|l|}{8.84} & 54.42 \\
\hline TOTAL & 26.53 & 29.25 & 27.89 & \multicolumn{2}{|l|}{16.33} & 100.00 \\
\hline \multicolumn{3}{|c|}{ Test statistic } & \multicolumn{2}{|r|}{ Value } & DF & Prob \\
\hline \multicolumn{3}{|c|}{ Pearson Chi-square } & \multicolumn{2}{|r|}{13.808} & 2 & .003 \\
\hline
\end{tabular}

bargaining principals in the two significant areas of working conditions: Autonomy and Formal Contracts (see Table I). The analysis revealed a significant effect for this control variable on the dependent variable with regard to autonomy at the .03 level. The analysis of variance also identified a significant effect for this control variable on the dependent variable of formal contracts at the .01 level (see Table VII). The data suggests the factor of suburban district (which is not as closely matched as the other classifications between the two states) has a significant effect on determinants of autonomy and formal contracts. There were more respondents from suburban districts in washington than from oregon. 
TABLE VII

IEVEL OF SIGNIFICANCE AS DETERMINED BY A ONE-WAY ANALYSIS OF VARIANCE OF DISTRICT CLASSIFICATION AND WORKING CONDITIONS FOUND SIGNIFICANT.

\begin{tabular}{llll}
\hline $\begin{array}{l}\text { Primary Analysis } \\
\text { Working Condition }\end{array}$ & $\begin{array}{l}\mathrm{F} \\
\text { Ratio }\end{array}$ & $\begin{array}{c}\text { Significant } \\
\text { Level } \\
\mathrm{p}=<.05\end{array}$ & $\mathrm{DF}$ \\
\hline Autonomy & 3.152 & .027 & 3,138 \\
Formal Contracts & 3.483 & .011 & 3,138 \\
\hline
\end{tabular}

Secondary Analysis

Working Condition

\begin{tabular}{lccc}
\hline Salary & 8.246 & .000 & 3,140 \\
Power/Authority & & NS \\
Job Security & NS & \\
Fringe Benefits & NS & \\
Role Definition & 10.778 & .00 & 3,138 \\
Decision Making & 3.136 & .028 & 3,137 \\
\hline NS $=$ Not Significant & & & \\
\hline
\end{tabular}

See Appendix $C$ for additional analysis of variance statistics. 
An analysis of variance was also conducted to determine the effect of district classification on the levels of bargaining for each of the six working conditions found significant with regard to level of bargaining: 1) salary, 2) role definitions, 3) power and authority, 4) involvement in decision making, and 5) fringe benefits.

As noted in Table VII, the analysis of variance revealed a significant effect by this control variable in the area of salary at the .00 level, the area of role definition at the .00 level and the area of decision making at the .03 level based on a significant level of .05. It appears there is a significant effect on those three working conditions based upon district classification.

\section{District Size}

The questionnaire asked respondents to categorize the size of the districts they represented. Districts were divided into three categories:

1) Small 0 - 999 students

2) Medium 1000 - 4999 students

3) Large 5000 - larger students.

This demographic variable was found to be significant at the .05 level (See Table VIII). The significance is attributed to the numbers of principals responding in the large district category. There were considerably more respondents from large districts in washington than from Oregon. 
TABLE VIII

CHI SQUARE TEST OF SIGNIFICANCE COMPARING BARGAINING AND NON-BARGAINING PRINCIPALS WITH DISTRICT SIZE.

PERCENTS OF TOTAL

\begin{tabular}{|c|c|c|c|c|c|c|}
\hline & LARGE & MEDIUM & SMALL & \multicolumn{2}{|c|}{ TOTAL } & \\
\hline OREGON & 10.96 & 21.92 & 13.01 & \multicolumn{2}{|c|}{45.89} & \\
\hline WASHINGTON & 24.66 & 19.86 & 9.59 & \multicolumn{2}{|c|}{54.11} & \\
\hline TOTAL & 35.62 & 41.78 & 22.60 & \multicolumn{2}{|c|}{100.00} & \\
\hline \multicolumn{2}{|c|}{ TEST STATISTIC } & & & & $\mathrm{DF}$ & PROB \\
\hline PEARSON $\mathrm{CH}$ & QUARE & & & & 2 & .022 \\
\hline
\end{tabular}

Analysis of variance was conducted to determine the effect of demographic variable of district size on the independent variable of bargaining and non-bargaining principals. The only dependent variable of working conditions found to be significant was formal contracts. The analysis of variance found the effect to be significant at the .03 level, based on a significance level of .05 (See Table IX). The number of principals responding from large districts in Washington, when compared with the number of principals in Oregon, has a significant effect on the area of formal contracts. 
TABLE IX

LEVEL OF SIGNIFICANCE AS DETERMINED BY A ONE-WAY ANALYSIS

OF VARIANCE OF DISTRICT SIZE AND WORKING CONDITIONS FOUND SIGNIFICANT.

\begin{tabular}{|c|c|c|c|}
\hline $\begin{array}{l}\text { Primary Analysis } \\
\text { Working Condition }\end{array}$ & $\begin{array}{l}\text { F- } \\
\text { Ratio }\end{array}$ & DF & $\begin{array}{c}\text { Level of } \\
\text { significance } \\
p=<.05\end{array}$ \\
\hline Autonomy & & & NS \\
\hline Formal Contracts & 3.786 & 2,138 & .025 \\
\hline \multicolumn{4}{|l|}{$\begin{array}{l}\text { Secondary Analysis } \\
\text { work Condition }\end{array}$} \\
\hline Salary & 10.642 & 2,140 & .00 \\
\hline Power/Authority & 2.959 & 2,129 & .055 \\
\hline Job Security & & & NS \\
\hline Fringe Benefits & & & NS \\
\hline Role Definition & 12.504 & 2,138 & .00 \\
\hline Decision Making & & & NS \\
\hline
\end{tabular}

NS $=$ Not Significant

See Appendix $C$ for additional analysis of variance statistics. 
An analysis of variance was also conducted to examine the effect of district size on the levels of bargaining and working conditions which were statistically significant in the Secondary Analysis section. These were salary, role definition, power and authority, and involvement in decision making.

As noted in Table IX, this analysis showed district size to have a significant effect upon salary $(.00)$, role definition $(.00)$, and power and authority (.05 level).

\section{Analysis of Covariance}

Since district classification and size of district significantly vary between bargaining and non-bargaining principal groups (see Demographic Data Analysis section), these variables were used as covariates in an ANCOVA analysis of the six significant determinants of working conditions. Three of the six analyses were found to be statistically significant (see Table X).

The analysis of covariance determined the effect of district classification and district size upon the independent variable of bargaining and non-bargaining principals and its impact on the dependent variable of autonomy. After adjusting for the two covariates, the significant difference was at the .01 level. A statistical test at the .05 level of rejection was conducted. The primary analysis sub-hypothesis that there is no significant difference in bargaining and non-bargaining 
TABLE X

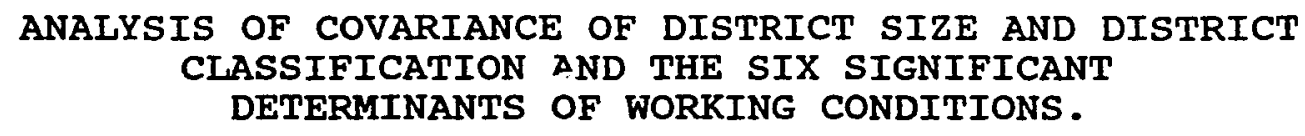

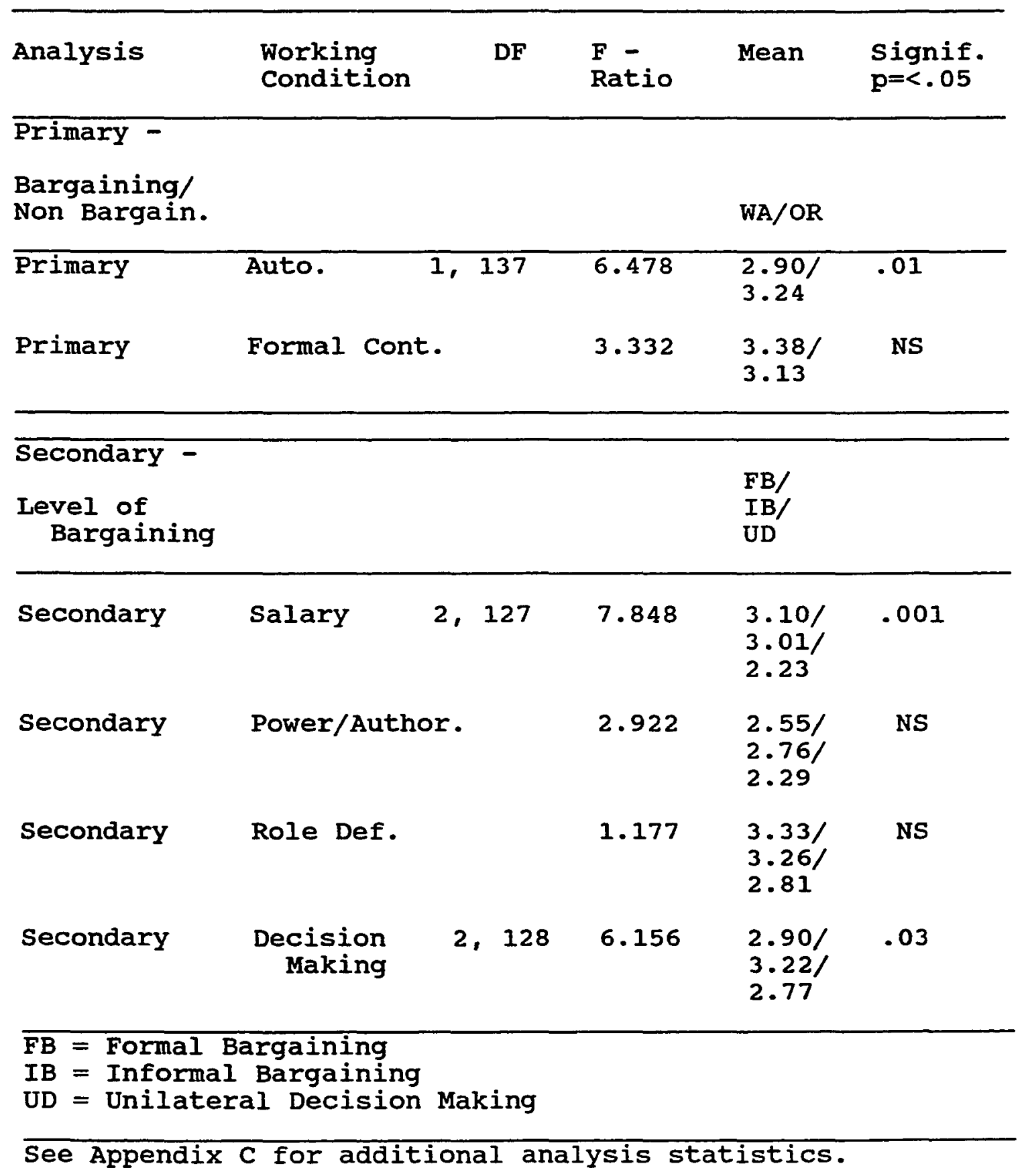


principals with regard to autonomy was rejected. There appears to be a significant difference between bargaining and non-bargaining principals with reference to their perception of autonomy (see Figure 7).

For a secondary level of analysis (the level of bargaining), two determinants were significant. The first measured the effect of district classification and district size on the independent variable level of bargaining and its impact on the dependent variable of salary. Adjusting for the two covariates, a .00 level of significance was calculated (See Table $\mathrm{X}$ ). The sub-hypothesis that there is no significant difference in the level of bargaining with regard to salary was rejected based upon a test at the .05 level of significance.

The second analysis of covariance measured the effect of the covariates upon the level of bargaining relative to involvement in decision making. After adjusting for the two covariates, the level of significance was adjusted to .00 (See Table $X$ ) . The secondary sub-hypothesis was rejected based on a .05 rejection level. The hypothesis states there is no significant difference in the level of bargaining with regard to involvement in decision making.

Even after adjusting for other significant factors, both salary and involvement in decision making appear significant. An analysis of covariance was not used to analyze the data regarding fringe benefits and job security as they had 
already been determined to be significant through the analysis of variance. The demographic data was not found to have any significant effect on their significance and therefore, an analysis of covariance was not necessary. The data analysis identified differences in the perceptions of principals who participate in formal bargaining, principals involved in informal bargaining and those who accept unilateral decisions. Principals involved in formal bargaining report significantly higher mean responses in the area of salary than those who informally bargain or who are recipients of unilateral decisions (see Figure 8). Principals who informally bargain report significantly higher mean scores relative to involvement in decision making, fringe benefits and job security than those who participate in formal bargaining or unilateral decision making models.

\section{SUMMARY}

This chapter presented an analysis of the data for this investigation. The activities included 1) analysis of the nine areas of working conditions, 2) analysis of the level of bargaining and perceptions of working conditions, 3) demographic analysis with seven sub hypotheses, and 4) an analysis of covariance (see Table XI) .

The primary analysis compared bargaining and nonbargaining principals using nine determinant areas of working conditions in which two areas were found to be significant: 
TABLE XI SUMMARY OF SIGNIFICANT DETERMINANTS OF WORKING
CONDITIONS IN EACH ANALYSIS.

\begin{tabular}{|c|c|c|c|}
\hline Analysis & $\begin{array}{l}\text { Horking } \\
\text { Condition }\end{array}$ & $\begin{array}{l}\text { F- } \\
\text { Ratio }\end{array}$ & $\begin{array}{r}\text { Significance } \\
p=<.05\end{array}$ \\
\hline Analysis & Formal Contracts & 6.122 & 0.015 \\
\hline $\begin{array}{l}\text { Bargain/Hon-bargain } \\
\text { ANOVA }\end{array}$ & Autonomy & 7.934 & 0.006 \\
\hline Secondary & Salary & 10.969 & 0.000 \\
\hline \multirow{5}{*}{$\begin{array}{l}\text { Level } \\
\text { ANOVA }\end{array}$} & Power/Authority & 3.927 & 0.022 \\
\hline & Job Security & 4.509 & 0.013 \\
\hline & Fringe Benefits & 4.238 & 0.016 \\
\hline & Role Definition & 3.612 & 0.030 \\
\hline & Decision & 6.046 & 0.003 \\
\hline Denographic & Autonomy & 3.152 & 0.027 \\
\hline of District size and/ & & & \\
\hline or Classification & \multirow[t]{2}{*}{ Formal Contracts } & $3.483 /$ & $0.025 /$ \\
\hline & & 3.786 & 0.011 \\
\hline & Salary & 8.246 & 0.000 \\
\hline & Role Definition & 10.778 & 0.000 \\
\hline & Power/Authority & 2.959 & 0.055 \\
\hline & Decision & 3.136 & .028 \\
\hline $\begin{array}{l}\text { Primary } \\
\text { AkCova }\end{array}$ & Autonormy & 6.478 & 0.012 \\
\hline \multirow{2}{*}{$\begin{array}{l}\text { Secondary } \\
\text { ANCOVA }\end{array}$} & Salary & 7.848 & 0.001 \\
\hline & Decision & 6.156 & 0.030 \\
\hline \multirow[t]{2}{*}{ ANCOVA NOT NEEDED } & \multirow{2}{*}{$\begin{array}{l}\text { Fringe Benefits } \\
\text { Job Security }\end{array}$} & 4.238 & 0.016 \\
\hline & & 4.509 & 0.013 \\
\hline
\end{tabular}


1) formal contracts and 2) autonomy. The secondary analysis compared level of bargaining with the same determinant areas. Six areas were statistically significant: 1) salary, 2) power and authority, 3) job security, 4) fringe benefits, 5) role definition and 6) decision making.

The two demographic factors found to be statistically significant were: District classification and District size. After conducting an analysis of variance using these two demographic variables, the significant determinant working condition areas effected by the demographic variables in both the primary and secondary analysis were: 1) autonomy, 2) formal contracts, 3) salary, 4) role definition, 5) decision making, and 6) power/authority.

The analysis of covariance revealed, even after adjusting for the two covariates of district classification and district size, three working condition areas as still statistically significant. In the primary data analysis, there remained a statistically significant difference between bargaining and non-bargaining principals relative to autonomy. The null hypothesis was therefore rejected. This hypothesis states there is no significant difference between the two principal groups in the area of autonomy.

In the secondary data analysis, there remained a statistically significant difference between the level of bargaining with regard to the determinants of salary, involvement in decision making, job security, and fringe 
benefits. In the secondary analysis, four sub-hypotheses were also rejected. These are:

1) There is no significant difference in the three levels of collective bargaining relative to the perception of salary.

2) There is no significant difference in the other levels of collective bargaining relative to the perception of involvement in decision making.

3) There is no significant difference in the three levels of collective bargaining relative to the perception of job security.

4) There is no significant difference in the three levels of collective bargaining relative to the perception of fringe benefits.

Chapter V reports the study's findings, conclusions and recommendations based on the analysis provided in chapter IV are discussed. 


\section{CHAPTER V}

FINDINGS, CONCLUSIONS, AND RECOMMENDATIONS

This chapter begins with a review of the problem statement, research design, and data analysis. It is followed by a discussion of the study's findings and their implications for policy and practice. The chapter concludes with suggestions for future research into collective bargaining for educational administrators.

\section{STUDY SUMMARY}

\section{Review of the Problem}

The legitimacy of administrative collective bargaining in public education has gained greater acceptance in recent years. Although collective bargaining for school principals flourished during the sixties and seventies, during the last fifteen years there have been very few changes or significant developments in collective bargaining for administrators. Correspondingly, the publics' attitude toward educational administration has been mixed as indicated in the review of literature in chapter II.

organizational theory and the history of the American Labor Movement have greatly influenced the right of school principals to organize for the purpose of collective bargaining. Various theories support the need for principals 
to achieve higher order need satisfactions. Maslow's (1954) theory is based on the idea that motivation is an eternal force which cannot be imposed by external effort. Frederick Herzberg (1966) found that contented workers derived satisfaction directly from job satisfiers and motivators. Blau (1978) speaks to the "exchange theory" as the give and take of services in exchange for wages and benefits. The assumption is that men seek to adjust social conditions to achieve their ends is realistic and inescapable. Specific forms of social organization, such as unions are the result of the exchange process. The patterns of conduct by individuals or groups and their relations readjust through the process of exchange and competition (Blau, 1978).

When school boards establish with principals the means for openly discussing and acting on relevant concerns such as wages, role definition, autonomy, and authority it may enhance in principals, a greater sense of professional recognition and esteem (Caldwell and Paul, 1983).

Principals in many school districts do not have the same access to negotiated decision making as do their subordinates (teachers) who are involved in collective bargaining (Caldwell and Paul, 1983). This decision making process with respect to wages, benefits and self-interest is an acceptable practice to upper management in public and private sector organizations. In education, upper management (school boards and superintendents) tend to hold more tightly to unilateral one-sided decision making due to the negative public attitudes 
which have emerged as a result of teacher collective bargaining.

Principals have used collective bargaining as a means of accessing the decision making process to get greater input with respect to wages, benefits, and overall working conditions. Many principals have felt pushed into collective bargaining because decisions made by school boards have adversely effected principals' jobs.

Teachers' roles in collective bargaining have also pushed administrators toward a collective bargaining model, and administrators see negotiations going on around them but seldom with them. Bargaining between top management and teachers, in which principals do not participate, has undermined their prerogatives when viewing the gains made by teachers in salary and other welfare issues. It is not surprising that the process had appeal to principals.

The principal's role in school site management is putting policy into practice. Administering the teacher contract is a major part of this policy management for principals, but they have less authority than the teachers in developing the bargaining process and the contract.

Principals are "caught in the middle" of collective bargaining dynamics. Although they are expected to administer narrowly defined practices as prescribed by the teacher contract, many do not have direct access to formalized channels of input to their governing boards in defining 
principals' working conditions, that the collective bargaining process would bring. However, participation in the collective bargaining process means participating in an adversarial model.

Proponents of the "administrative team" concept feel it is the major victim of principals' right to collectively bargain. The adversarial aspects of bargaining make the "administrative team" concept impossible to implement.

collective bargaining for administrators in oregon and Washington differs based on the legal statutes within each state. In Oregon the legislature did not develop a statute to encourage collective bargaining. It was left to the local control of each district to determine the process. In Washington, a statute was developed and implemented with rules and regulations guiding the collective bargaining process for principals.

This study examined the perceptions of public school principals in oregon and washington regarding working conditions and analyzed the relationships between principals' perceptions and their ability to collectively bargain.

From a review of the social/behavioral science literature, two research questions were developed to guide the study.

1) Do school principals who can legally bargain collectively for their working conditions perceive these conditions differently than principals who can not? 
2) What is the relationship between the level of collective bargaining and public school principals' perceptions of working conditions?

The research question which guided the study and from which the primary hypothesis was developed was question number one. From the first research question, the following primary research hypothesis was developed:

There is no significant difference in the perceptions of bargaining principals and non-bargaining principals regarding working conditions.

The following sub-hypotheses were developed to guide this part of the study. The primary analysis tested the following sub-hypotheses:

1. There is no significant difference in the perceptions of bargaining principals and non-bargaining principals regarding salary.

2. There is no significant difference in the perceptions of bargaining and non bargaining principals relative to the existence of formal written contracts.

3. There is no significant difference in the perceptions of bargaining and non-bargaining principals relative to autonomy.

4. There is no significant difference in the perceptions of bargaining principals as compared to non-bargaining principals relative to power and authority.

5. There is no significant difference in the perceptions 
bargaining and non-bargaining principals relative to job security.

б. There is no significant difference in the perceptions of bargaining and non-bargaining principals relative to fringe benefits.

7. There is no significant difference in the perceptions of bargaining and non-bargaining principals relative to role definition.

8. There is no significant difference in the perceptions of bargaining and non-bargaining principals in the level of communication with school boards and superintendents. 9. There is no significant difference in the perceptions of bargaining and non-bargaining principals relative to their involvement in decision making.

The second research question which guided the study was: What is the relationship between the level of collective bargaining and public school principals' perceptions of working conditions?

From the second question, the following secondary hypothesis was developed:

There is no significant difference between the level of bargaining of principals and their perceptions of working conditions.

The following sub-hypotheses were developed from the secondary hypothesis:

1. There is no significant difference in the three 
levels of collective bargaining relative to the perception of salary.

2. There is no significant difference in the three levels of collective bargaining relative to the perception of the existence of formal written contracts. 3. There is no significant difference in the three levels of collective bargaining relative to the perception of autonomy.

4. There is no significant difference in the three levels of collective bargaining relative to the perception of power and authority.

5. There is no significant difference in the three levels of collective bargaining relative to the perception of job security.

6. There is no significant difference in the three levels of collective bargaining relative to the perception of fringe benefits.

7. There is no significant difference in the three levels of collective bargaining relative to the perception of role definition.

8. There is no significant difference in the three levels of collective bargaining relative to the perception of the level of communication with the school board and superintendent.

9. There is no significant difference in the three levels of collective bargaining relative to the 
perception of involvement in decision making.

\section{Research Design}

The population for this study consisted of all elementary, middle level, and secondary public school principals in oregon and Washington.

To insure the sample would be representative of all school principals, a simple random sample procedure was utilized. A list of all principals was obtained from the Oregon and Washington State Departments of Education. The names on each list were consecutively numbered, excluding those principals who also served as superintendent in their respective districts. Using a computerized random numbers chart for each list, a sample of one hundred principals from each state was drawn.

The sample represented approximately ten percent of the total population available for study. Eighty (80) Washington principals and sixty-seven (67) oregon principals responded to the questionnaire for an overall return rate of seventy three and one half $(73.5 \%)$ percent. This sampling technique enabled the investigator to learn more about the perceptions of school principals in both washington and oregon.

Washington and oregon were chosen in order to obtain responses from principals in one state, who by state statute, may collectively bargain and to compare their responses to those of principals working in a state which does not have 
statutory authority for administrative collective bargaining.

Data were collected through use of the School Principal Working conditions Questionnaire. This instrument was developed by the researcher, adapted from a combination of the Middle Management Working Conditions Questionnaire developed by Williams (1985), and The Principal Attitude Questionnaire...Non-Union and The Principal Attitude Questionnaire...Union by Morris (1985). All data were analyzed utilizing the SYSTAT (The System for Statistics) microcomputer statistical package.

In analyzing the data, items pertaining to each of the nine determinant areas of working conditions were grouped, totaled and averaged. A one-way analysis of variance was used to compare the perceptions of bargaining and non-bargaining principals in each of the nine determinant areas of working conditions. These data were not treated as ordinal, but were collapsed to simulate interval data and a one-way analysis of variance technique was utilized to analyze the data set.

Respondents' answers were grouped into categories representing three levels of collective bargaining: formal collective bargaining, 2) informal, and 3) unilateral decisions. A one-way analysis of variance was used to compare principals' responses.

When a demographic factor was found to significantly vary between bargaining and non-bargaining principal groups, this variable was used as a covariate and an analysis of covariance 
was conducted. Analysis of covariance helped to explain the effects of the primary independent variable (bargaining/non bargaining) without the effect of the demographic factor.

\section{FINDINGS}

Results of the data analysis are reported in the order the questions are stated:

1) Do school principals who can legally bargain collectively for their working conditions perceive these conditions differently than principals who can not?

2) What is the relationship between the level of collective bargaining and public school principals' perceptions of working conditions?

Question one guided the development of the primary hypothesis addressed in the study: There is no significant difference in the perceptions of bargaining principals versus non-bargaining principals concerning working conditions.

To test this hypothesis, mean scores of the satisfaction ratings of Washington principals were compared to the mean scores of the ratings for oregon principals in each of nine determinant areas of working conditions. The data indicates that Washington principals (legally authorized to bargain) recorded higher mean scores than did Oregon principals (nonbargaining) in only one area which was statistically significant, the Existence of Formal Contracts. Oregon principals recorded a significantly higher mean score than 
Washington principals in the area of Autonomy. According to the analysis of variance results, the .05 level of significance was achieved in both of these areas (See Table XI). The results of the analysis of covariance, indicate only the area of Autonomy was significant at the .05 level (see Table XI). There were no significant differences between the two groups in the areas of 1) salary, 2) power and authority, 3) job security, 4) fringe benefits, 5) role definition, 6) communication, and 7) decision making.

There still remained a statistically significant difference relative to the variable of autonomy for the two groups of principals. Non-bargaining principals (oregon) perceive the autonomy they possess in managing their buildings to be higher than do bargaining principals (Washington). The explanation for this finding may be attributable to the notion that collectively they have no impact upon district collective bargaining processes but as school site managers, they are able to make a difference in the education of children and they do have impact on teacher behavior. Another view may be that decisions made at the district level have little or no impact at the building level and the principal has more independence in all aspects of school management, including working with the superintendent, regarding conditions of work. Principals are more involved in all decisions which impact them directly. These decisions may not directly impact working conditions, but the principals involvement in the 
process affects their perceptions of autonomy. There may not be a division between the decision process regarding school management and principals' business as in Washington, where the decision making process regarding working conditions may be different than other decision making processes.

The second research question, with regard to the level of bargaining and its impact on principals' perceptions of working conditions, guided the secondary hypothesis: There is no significant difference between the level of bargaining of principals and their perceptions of working conditions. A secondary analysis was conducted to determine levels of bargaining which significantly impacted the perceptions of principals working conditions. Mean scores of principals' responses to levels of bargaining were compared with the nine determinant areas of working conditions. Analyses of variance and covariance indicated only four determinants were statistically significant. For the formal collective bargaining group, the area of salary (.001) was significant. Decision making (.030 level), job security (.013), and fringe benefits $(.016)$ were significant for the informal bargaining group (see Table XI, chapter IV).

There were no significant differences between the two principal groups in the level of bargaining and the areas of 1) autonomy, 2) formal contracts, 3) power and authority, 4) role definition, and 5) communication.

The relationship between formal bargaining and salary 
perceptions appears to be tightly coupled. For example, principals who indicated they formally bargained had a significantly higher mean score than did principals who indicated an informal level of bargaining or those who belonged to the unilateral decision making group. This perception suggests that one factor which may contribute to higher levels of satisfaction with the adequacy of salary for principals is the formal collective bargaining process. Anderson (1970) notes substantial gains in salary and other welfare issues have been made by teachers through the formal collective bargaining process. This is similar to the results indicated in the research by Lecesne (1980), where a positive correlation between formalized bargaining and the degree of satisfaction with adequacy of principals' salaries.

In the areas of involvement in decision making, job security, and fringe benefits, the group of principals claiming to have informal levels of bargaining had significantly higher mean scores than principals who indicated a formal level of bargaining or those engaged in unilateral decision making processes. An explanation for this finding is they are involved in the decision making process more often or to a greater extent than those principals in the formal and unilateral levels of bargaining. This may be characteristic of informal bargaining processes which incorporate the "administrative team" concept.

As in the area of involvement in decision making, 
principals' participation in informal bargaining may bring about greater interaction between the principals and superintendent or school board in establishing specific policies and procedures that principals perceive to impact their job security. This interaction can offer increased opportunities for professional growth for all members of the team. Increased collaboration can lead to an increase in the professionalism of the team and bring about greater fringe benefits. Principals in this study reported more fringe benefits, including professional memberships, leaves, and professional growth opportunities, through informal bargaining processes.

An informal process or administrative team concept allows for greater interaction between groups. This interaction may result in participants perceiving higher degrees of involvement in managerial decision making as well as greater degrees of involvement in decisions which impact upon working conditions.

\section{CONCLUSIONS}

The data from this study indicate that principals who have legal authority to bargain collectively do not perceive their working conditions to be significantly better than principals who cannot bargaiñ. Only one of nine determinants of working conditions, autonomy, was found statistically significant (see Table XI, Chapter IV), and it was higher for 
non-bargaining principals.

A major conclusion of this study is there are no significant differences between oregon and washington principals relative to working conditions. There are several factors which might contribute to the perceived lack of difference between the two groups of principals. The first is the bargaining level of the principals (see Table II, Chapter IV). There is little difference in the perceptions of principals in each of the three bargaining level groups formal, informal, and unilateral decision making. Principals' responses in both states reveal a similar pattern even though statutory authority for formal bargaining differs greatly in each state.

Another factor which may contribute to the lack of significant differences between oregon and Washington is the progressiveness of the educational systems in both states relative to level of bargaining. Both states' largest group of respondents were principals who had an informal level of bargaining. This "getting to yes" style of bargaining is coming into vogue for teacher negotiations as well as in administrative negotiations. The current trend is away from adversarial bargaining and there may be a comparable decline in interest in formal bargaining by principals. In the 1990's administrator collective bargaining may not be the preferred strategy by principals.

A third factor which may explain the similarities of both 
principal groups is a satisfaction with current working conditions and a corresponding view that teacher groups are not continuing to make substantive gains in either salary or other welfare issues. The needs that have traditionally led principals to organize may not be there now (Barea, 1978) and job satisfaction may be at higher levels. As indicated in the study by Sweeney and Rowedder (1982), principals reporting greater satisfaction with salaries and benefits were not strongly pro-union. This study, of oregon and Washington principals, concurs with the findings of Nasstrom and Pier (1983) and Morris (1985), who concluded principals who have statutory authority to collectively bargain do not perceive their working conditions to be significantly more positive than principals who do not have this authority.

The findings indicate the level of collective bargaining has some effect on the principals' perceptions of working conditions but not at a statistically significant level. These conclusions, and those which follow, are drawn from the data which show that salary, involvement in decision making, job security, and fringe benefits were found to be statistically significant factors with regard to the principals' level of bargaining.

The data indicates that principals who formally bargain have higher scores on adequacy of salary scales than the other two respondent groups. In support of the research conclusions by Lecesne (1980), Caldwell (1981), Sweeney and Rowedder 
(1982), and Nasstrom and Pier (1983), there appears to be a positive relationship between the degree of formalized interaction between principals and their school boards relative to contractual items. This formalization results in a significantly more positive perception of salary adequacy.

Principals perceive higher levels of involvement in decision making, job security, and fringe benefits through the informal bargaining process over the formal level. This may be attributed to the implementation of an "administrative team" concept and a shared power structure in which principals have greater latitude and involvement in decision making. The idea is to involve principals in more decisions including those which effect their working conditions. A less formalized model may also alleviate the adversarial relationships in collective bargaining (Caldwell and Paul, 1983 and Kowalski, 1978), and make the school board and/or the superintendent more comfortable in joining forces with an administrative team.

This "shared power" or "informal" structure may prove superior to the adversarial aspects of formal bargaining and make the achievement of a true administrative team possible. In Washington and Oregon, both the Confederation of oregon School Administrators (COSA), Washington Association of School Administrators (WASA) and the Association of Washington School Principals (AWSP) are supporters of the administrative team concept. 
Previous research on administrative collective bargaining has generally concluded that principals who are involved in formal or informal collective bargaining (whether or not this activity is permitted by state statute) have more positive perceptions of their working conditions. This study also found mean scores on working conditions sub-scales for principals in the informal and formal bargaining groups to be higher than those for principals in the unilateral decision making group.

\section{IMPLICATIONS}

\section{Policy}

Many legislative bodies are currently debating the issue of collective bargaining for administrators. Legislators are evaluating collective bargaining statutes and their implementation. The findings of this study provide data which can inform those responsible for the development of such statutes. The data may be persuasive for the development of statutes which insure that the statutes have language that focuses on interactive practices which will encourage school boards, superintendents and principals to employ a two-way communication strategy for decision making with regard to working conditions. An administrative team model could enhance professionalism for all groups involved in educational decision making.

Local policy makers could establish this type of policy 
at the local level within their school board policies and procedures to insure involvement by principals in matters that relate specifically to working conditions. An effective administrative team model may have an even broader scope to include a "shared power model" which could be truly representative of a participatory management model.

\section{Practice}

Those responsible for implementing policy, the practitioners, could benefit from this study's findings that the formalization of collective bargaining may not be as important as the actual practice of involvement of principals in establishing procedures in the area of job security and the types of benefits principals' receive. As Caldwell (1981) found in his study, the actual process through which working conditions are determined is more crucial in job satisfaction than the actual level of the conditions.

\section{Theory}

Principal involvement is establishing conditions of work is based on the idea of meeting the basic needs of principals so that they are able to achieve the maximum effectiveness permitted by their abilities and skills (Lutrin, 1985). When school boards establish with principals the means of openly discussing and acting on relevant concerns, it enhances the principals' sense of professional recognition (Caldwell and Paul, 1983). 
According to Blau (1978) in the exchange theory, collective organization mobilizes power. Also, a person or group who commands services other's need, attains power over others. If there is an imbalance in the power level, there will be an uneven exchange between the groups. School boards, by not anticipating in advance the social regards or needs which principals will or can reciprocate in the exchange relationship, inevitably will bring error and uncertainty into the relationship of the groups (Blau, 1978). Blau's exchange theory (1978) can be used as a conceptual model for collective bargaining. This exchange theory can be referred to as the "give and take" of services in exchange for wages and benefits. The assumption is that people seek to adjust social conditions to achieve their ends. Specific forms of social organization are the result of the exchange process (Blau, 1978). Union organization is an example of this form of social organization. The patterns of conduct by individuals or groups and their relations readjust through the process of exchange and competition according to Blau (1978). This pattern of conduct could be the informal or formal process of collective bargaining.

Providing a model which encourages discussion and input by the school board, superintendent and principals before final decisions with regard to working conditions are made helps avoid an imbalance in power levels. Subsequently, both groups can experience gratification. 


\section{Limitations}

There were limitations on this study which may be corrected in future studies. First, sampling for the study was limited to a survey of a specific geographical population. Therefore, it is recommended this study be replicated using a larger number of oregon and washington school principals in order to have more generalizable data about principals' perceptions of their working conditions. second, in the secondary analysis, a planned comparison could be made between the three levels of bargaining to further determine significance between the formal bargaining group and the informal bargaining group. This planned comparison can only be done if certain data are known ahead of time and the statistical analysis is planned.

\section{RECOMMENDATIONS}

1. The findings of this study become part of a nationwide survey of collective bargaining statutes for principals. There are elements in this study and in previous studies that are consistent. However, future studies might show different trends if, for example, principal collective bargaining studies were conducted in each state.

2. Studies examining successful labor processes, other than collective bargaining, are needed. A review of the literature indicates principals want involvement in decision making about working conditions, but no where is it cited that 
the vehicle must be formal collective bargaining. There may be other labor relations models utilized by school board members which take into account the needs of principals, school boards, teachers, students, and parents. These models may be more effective than the existing adversarial collective bargaining model. The data for this study revealed a greater number of respondents were involved in informal types of bargaining. Both groups chose strategies other than formal bargaining, whether or not they had access to more formal procedures. Therefore, a question for further research could be, "If formal collective bargaining is not the best means of setting working conditions for school principals, what model or process best meet the needs of this professional group?"

3. Many Oregon respondents reported they were involved in some aspect of collective bargaining even though there is no statutory authority for these bargaining activities. Oregon principals' knowledge of collective bargaining statutes and their perceptions of administrative collective bargaining needs further probing. A descriptive study of oregon principal's perceptions of formal collective bargaining and the process they use for categorization needs to be conducted. Such a study would help clarify the bargaining processes being employed throughout the state.

4. A study designed to compare the roles of middle managers in other fields and school principals may provide insight into the human relations aspect of future 
organizational dynamics in education. Such a study could be designed to answer the research question "Do middle managers in fields other than education have a model they use to reach agreement on issues specific to their working conditions? Does this model involve the middle managers in the decision making process?"

5. The demographic data for this study was only tested for significance with regard to the independent variable of bargaining (Washington) and non-bargaining (Oregon) principals. A further investigation of these factors with regard to the nine determinants of working conditions may provide some interesting findings.

6. Finally, a further investigation into the reasonableness of changing state statutes to move toward an administrative team concept or shared power model, relative to collective bargaining of principals' working conditions, is needed. An initial study to survey legislators about their attitudes regarding collective bargaining and administrative team structures would be an initial step in this line of inquiry. The education profession could benefit from information about the "reasonableness" of proposing any kind of change in statutes in either oregon or Washington.

Further study should also seek to identify those districts which use an administrative team model with regard to conditions of work rather than a formal collective bargaining model. This should be done after pin-pointing the 
contextual factors, as well as the structures and processes which influence principals in districts using this model. The investigator could work with $\operatorname{COSA}$, WASA and AWSP to develop legislative proposals for shaping administrative team statutes.

\section{SUMMARY}

This chapter provides a summary of the research comparing bargaining and non-bargaining principals' perceptions of working conditions. The study's findings indicate non-bargaining principals (Oregon) perceive autonomy at higher levels than do bargaining principals (Washington). Oregon principals when compared to Washington principals perceive themselves as having greater authority over teachers and school building activities. All the other determinants of working conditions were not found to be statistically significant. Overall, the existence of formal collective bargaining was found to have no significant impact on principals' perceptions of their working conditions.

A secondary data analysis found the determinants of 1 ) salary, 2) decision making 3) job security, and 4) fringe benefits to be significant relative to the level of bargaining. Principals who formally bargain perceive higher levels of satisfaction with the adequacy of their salary levels than do those principals who informally bargain or who accept unilateral decisions. 
Principals who bargain informally perceive higher levels of involvement in decision making, job security, and fringe benefits than do principals who formally bargain or accept unilateral decisions. These principals report they are involved in setting policy more often or to greater degrees than the other two respondent groups. They also perceive higher levels of job security and fringe benefits. The other five determinants of working conditions were not found to be statistically significant relative to the level of bargaining. Overall, the effect of the level of bargaining with regard to working conditions of principals was not significant.

This study's major finding that principals in washington, who by statute are allowed to bargain collectively, do not perceive they enjoy significant advantages regarding working conditions when compared with oregon principals, who do not have collective bargaining rights. This major finding has powerful implications for the collective bargaining movement and for principals in the Northwest. 


\section{REFERENCES}

Anderson, Lester w. (1970, May). Management team versus collective bargaining for principals. NASSP Bulletin, pp 170 - 171 .

Babbie, Earl R. (1973) . Survey research methods. Belmont, California: Wadsworth Publishing Co.

Barea, Norman (1978, May). Separate bargaining units - - A must for today's principal. NASSP Bulletin, May 1978, p. 44 .

Best, John W. and Kahn, James V. (1986). Research in education. Englwood Cliffs, New Jersey: Prentice Hall.

Bierstedt, R. (1964) - The problem of authority. New York: Octogon Press.

Blau, Peter J. (1978). Exchange and power in social life. New York: Wiley and Sons, Inc.

Blumberg, A., Brannigan, M. and Nason, D. (1981). Administrative power and collective bargaining in the schools. Journal of Collective Negotiations, 10, 327 336.

Bridges, E.M. (1982). Research on the school administrator: The state of the art, 1967-1980. Educational Administration Quarterly, 18, 12-33.

Bridges, E.M. and Cooper, B.S. (1977). Collective bargaining for school administrators: A significant development in the field of labor relations. Thrust for Education Leadership, 64, 25-26.

Caldwell, w. (1983, January). Principal compensation: A comparison and report. Principals Profile, pp. 4-8.

Caldwell, w., Hertzog, C., Riddle, R, and steinhart, D. (1981, April). Perceived job satisfaction of secondary school principals as related to the collective bargaining process. Paper presented at the annual meeting of the American Educational Research Association, Chicago. 
Caldwell, W. and Paul, D. (1983). Toward a higher level of trust. Planning and changing, 9, 131-136.

Chamberlain, Neil w. and Kuhn, James W., (1965). Collective bargaining. New York: McGraw Hill.

Cooper, B.S. (1976, January). The brewing - - and perhaps still preventable revolt of the school principals. American School Board Journal, pp. 25-27.

Cooper, B.S. (1976). Collective bargaining comes to school middle management. Education Digest, 42, 16-19.

Cooper, B. (1979, October). Collective bargaining for school administrators: Four years later. Phi Delta Kappan, pp. 64-67.

Cooper, Bruce S. (1982). Collective bargaining, strikes, and financial costs in public education: A comprehensive review. Administrators Notebook, 30 (3.) 66-69.

Cooper, B.S. and Murrman, K.F. (1982). Managerial identification and the unionization of school administrators. Administrators Notebook, 30 (1) , 103109 .

Cooper, B. and Nakamura, R. (1983). The unionization of school administrators: A study of public policy-making and labor relations. Washington D.C.: National Institute of Education.

Cunningham, Lurern L. (1968, April). Collective negotiations and the principalship. Theory Into Practice, p. 62 .

Deleonibus, N. and Thomson, S. (Eds.) (1980). Why principals quit - -and what can be done about it. The Education Digest, 45.

Forrest, James (1984, June). The leadership team: Is the strategy working. Thrust for Educational Leadership: Association of California School Administrators. pp. 3645 .

Gmelch, W.H. (1977, May/June). Beyond strengh to effective management. sosc Bulletin. pp. 45- 51 .

Hagburg, E.C. and Levine, M.J. (1979). Public sector labor relations. St. Paul, Minnesota: West Publishing Co.

Herzberg, Frederick (1966). Work and the nature of nan. New York: Collins Publishers. 
Hicks, H.G. (1967). The management of organizations. New York: McGraw Hill.

Hungerford, Nancy and Bischof, Bruce (1982). Oregon labor law today. Sunriver, Oregon: Labor Law Publishing Co.

Jascourt, Hugh (1984). Educational reform and its labor relations impact. Journal of Law and Education, 13 (3), 453-456.

Kanner, L. (1977, April). The changing role of administration. NASSP Bulletin, pp. 34-40.

Karlitz, H. (1978, November). Educational administrators and teacher unions: An alliance of convenience. The Clearinghouse, pp. 125-128.

Karlitz, H. (1979) . The unionization of educational administrators in the USA. International Review of Education, 25, 88-96.

Kerlinger, Fred N. (1973). Foundations of behavioral research. New York: Holt, Rinehart, and winston.

Kline, C.E. and Thomas, w. (1974). Middle administrators/ school board relationships in collective negotiations. Journal of Collective Negotiations, 3 , 49-56.

Knoester, W.P. (1977). The impact of middle management unionization on administrative decision making in selected Michigan school districts (Doctoral dissertation, Indiana state University). Dissertation Abstracts International, 38, 4484A.

Kowalski, Theodore J. (1978). Are you pushing your administration into collective bargaining? American School Board Journal, p. 35.

Lareau, M. (1980, March). The issues of collective bargaining for school administrators. Labor Law Journal, pp. 153164 .

Lazerson, A. (1975). Psychology today: An introduction. New York: Random House.

Lecesne, T. (1980, December) . Unionized principals - Why not? Phil Delta Kappan, pp. 283-284.

Lieberman, Myron (1970) . Collective negotiations for teachers. Chicago: Rand McNally. 
Likert, R. (1967). The human organization. New York: McGraw Hill.

Lutrin, Carl E. and Settle, Allen K. (1985). American public administration: Concepts and cases. Englwood cliffs, New Jersey: Prentice Hall.

Madsen, David (1983). Successful dissertations and theses. San Francisco, California: Jossey-Bass Inc.

Maslow, Abraham. (1954). Motivation and personality. New York: Harper and Row.

Mong, L. (1972). Unionized principals: Is your district next? Journal of Collective Negotiations, $\underline{36}(6)$, 165168 .

Morris, Tedd Roy, (1985). Middle management collective bargaining: The conditions of work and job satisfaction for elementary school principals in michigan, (Doctoral dissertation, Wayne state University). Dissertation Abstracts International. 46,05A, 14147 .

Mullins, C.E. (1982). Unit status of supervisors in public education: A union perspective. Journal of Law and Education, 11, 213-227.

Nasstrom, R. and Pier, C. (1983). Bargaining and nonbargaining principals. Planning and Changing, 9, 101108 .

Parsons, Talcott, (1954). Essays in sociological theory. Glencoe, Illinois: The Free Press.

Pisapia, J. (1980). The legal bases of administrative bargaining. NOLPE School Law Journal, 12 61-84.

Rodman, Blake. (1986, October). In an unprecedented move, administrators in philadelphia vote to join the teamsters. Education Week, p. 1.

Salancik, G.R. and Pfeffer, J. (1977). Who gets power and how they hang onto it. organizational Dynamics. 16 3-21.

Sinclair, J.E. (1977, Feb.). Separate bargaining units for principals - - the wrong solution. NASSP Bulletin, pp. 52-56.

Sisk, H.L. (1979). Principles of management. Cincinnati, Ohio: South Western Publishing. 
Smith, D.C. (1973). Professional negotiations and the principal: Should principals negotiate? National Elementary Principal, 52 109-110.

Smith, D.C. (1973). So you've decided to negotiate. National Elementary Principal 52, 125-128.

Smith, D.C. (1973). Professional negotiations and principals. National Elementary Principal, 52, 84-87.

State of oregon (1978). oregon law relating to public schools and community colleges. Salem, Oregon: Oregon Department of Education.

State of oregon (1982). oregon revised statutes. Salem, oregon: Oregon state Printing office.

State of Oregon (1982). Employment relations board: oregon Administration Rules. Salem, Oregon: Oregon state Printing office.

State of Washington (1975). Educational employment relations act, olympia, Washington: Superintendent of Public Instruction office.

State of Washington (1985). Revised Code of Washington. olympia, Washington: Superintendent of Public Instruction office.

Sweeney, J. and Rowedder, L. (1980). What principals want and get from their unions. The Executive Educator, $\underline{2}$ (23), 16-18.

Teacher burnout (1979, July). The Wall street Journal, a, p. 20 .

Thomas, clint (1981). Public school administrator collective bargaining. Unpublished manuscript, Portland state University, School of Education, Portland, Oregon.

Weber, Max (1947). The theory of social and economic organization. New York: Oxford Press

Webster's Third New International Dictionary (1986). Springfield, Massachusetts: Merriam Webster Inc.

Williams, John R., (1985). The relationship between middle management collective bargaining and selected school principals perception of their working conditions. (Doctoral dissertation, Lehigh University). Dissertation Abstracts International. 46,01A, 05025 . 
Yeager, R. (1974). Administrators turn teamster. Nation's Schools, 93, 18-19. 
APPENDIX A

TRANSMITTAL LETTERS 
12213 S. E. Riveridge Drive

Vancouver, WA 98684

February 2, 1988

Dear Colleague:

hinat you are about to read you have read nany times before...however, I believe, the end will justify the Deans. PLEASE READ ON!

I an a niddle school principal in the camas school District, in Camas, Washingtón, and a doctoral student at portland state tiniversity. I an doing research with Dr. John Heflin, my advisor, in the area of "Collective Bargaining for Educational idninistrators: Oregon and Washington Principals' Perceptions of horking Conditions."

Enclosed you will find a brief questionnaire. I a zequesting you take 10 to 15 minutes out of your busy schesile to complete it. You: candid response is greatly needed if. this research is to be successful. I have enclosed a self adiressed, stamped envelope for your converience and would very ruch appreciate your reะu=a is: Eebruary 12.

Since tineze are soge delicate issues addressec, ell retirns will ie :iept in the strictest confidence. Upon co=pletiun of the s=uiy, if you would be interested in seeing $a$ surwary of the zestizs, I would be happy to share this with you. SiIpi: dzop we 2 nc:e zequesting this information with your na:e and aciaress ana $\because=: \because \vdots i$ I Eceive a copy.

̈cu= orci=pt return of this ouestionnaire is crucizl to the siccess of ay study. your completion $c=$ the enclosed cuestion:aire is indication of your consent to parzicipate in inis stijy. I have enclosed a Baskin-Rojioins Ice cream certificaze as a "thank-you" and a token of Iy eppreciation for Your assistance in this research project.

:Oo:, doesn't this end justify the means. (If you are not totally satisfie:. please return the coupon for a full refuna.)

Inari: yc: for your cooperation.

sincerel:.

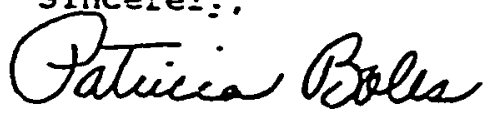

satricia i. Boles

Enclosures: Business Card

Baskin-Robbins Gift certificate 
February 12,1988

Dear Colleague,

Just a reminder that I have not as yet received the survey $I$ sent you on February 2. Your input is greatiy needed for a successful study of "Principals' Perceptions of Working Conditions in regards to collective Bargaining in oregon and Washington.

If you have already mailed your survey, thank you!

I realize what a busy time of year this is and how stressful one more request can be. If you have not done so, would you please complete and return the questionnaire as soon as possible. The survey is short and should take very little of your time.

I am very grateful for your help.

Sizcerely:

Gaturia Boles

Patri.cia Boles

Doctoral Candidate, Portland state University 
APPENDIX B

QUESTIONNAIRE 


\section{QUESTIONAAIRE}

\section{Instrictions for completing questionnaire}

The purpose of this questionnaire is to determine working conditions within your district and the degree of your satisfaction with these conditions.

1. State in which you work (check one)

Washington

oregon

2. School district classification (check one)

Urban
Suburban
Small Town
Rural

3. School district student population (check one)

$$
\begin{aligned}
0 & -999 \\
1000 & -4999 \\
5000 & - \text { larger }
\end{aligned}
$$

4. Date of Birth

5. Sex (check one)

\section{Male}

Female

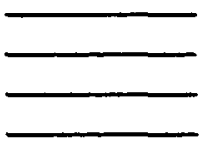


Please check the category/categories which best describe the process which results in determining salaries and working conditions for principals in your district: (Please check only one)

Formal collective bargaining between the
superintendent and representatives of
middle management.
Formal collective bargaining between
representatives of the school board and
principals
Informal meetings between the superintendent
/board and principals
Unilateral decisions by the superintendent/board
communicated to principals
other (Please specify)

Each of the following items makes a statement about administrative collective bargaining in the public schools. please read each statement carefully and then mark according to the following scale:

$$
\begin{array}{rr}
4 \text { - Strongly agree } & 2 \text { - Disagree } \\
3 \text { - Agree } & 1 \text { - Strongly } \\
& \text { Disagree }
\end{array}
$$

* Means

1.88 1. Administrative collective bargaining negatively effects the administrator's relationship with the teachers.

2.20 2. Administrative collective bargaining negatively effects the administrator's relationship with the superintendent.

2.21 3. Administrative collective bargaining negatively effects the administrator's relationship with the school board.

1.92 4. Administrative collective bargaining negatively effects the conditions of work for an administrator.

1.90 5. Administrative collective bargaining negatively effects the control an administrator has over their job responsibilities. 
Each item on this questionnaire makes a statement about the management in your schools. Please read each statement carefully. Then indicate the extent to which each stated condition actually exists in your school district, according to the following scale:

$$
\begin{array}{ll}
4 \text { - To a large extent } & 2 \text { - To a slight } \\
3 \text { - To a moderate extent } & 1 \text { - Not at all }
\end{array}
$$

* Means

3.09 1. An effective communication system exists between and among all levels of the management team.

3.06 2. Administrators meet periodically with the superintendent to discuss their problems.

2.28 3. Administrators meet periodically with school directors to discuss their problems.

3.33 4. Administrators have adequate opportunities to attend state conferences or conventions.

2.98 5. Administrators feel free to speak out at administrative meetings even if their views are contrary to the superintendent or Board.

2.78 6. There is wide involvement of administrators in the development of the school district budget.

3.36 7. Administrators have an opportunity to make appropriate input to employment decisions concerning school district employees.

3.30 8. Input from administrators is solicited as proposed administrative rules and regulations are being developed.

2.80 9. Administrators are represented on the board's negotiating team.

3.40 10. Job descriptions have been prepared for all administrators.

3.17 11. The district conducts formal performance appraisals with the administrators on a regular basis.

2.63 12. The district has a fair and logical procedure for determining salaries for administrators. 
2.87 13. Salaries for administrators compare favorably with their counterparts in similar districts.

3.00 14. The district has a fair and logical procedure for determining fringe benefits for administrators.

$\underline{2.96}$ 15. Fringe benefits for administrators compare favorably with their counterparts in similar districts.

3.68 16. Employment contracts have been provided for every administrator.

3.17 17. Collective administrator contracts are not changed without mutual consent.

2.64 18. The district has a staff development program for administrators.

2.58 19. Administrators feel free to implement new plans or policies for their schools or program responsibilities without involving a superior.

2.77 20. The district has defined, written hiring procedures for principals.

1.93 21. A written defined grievance procedure for administrators is in place.

3.50 22. There is a defined, written work year for the principals in the district.

3.25 23. The district has a defined, written salary structure for the principals.

2.75 24. Written procedures defining leaves of absence have been developed for all administrators.

3.40 25. Administrators meet periodically with the superintendent to resolve problems.

1.86 26. Administrators meet periodically with the school board to resolve problems.

2.61 27. Administrators have adequate opportunities to attend national conferences or conventions.

3.09 28. Administrators feel free to speak out at administrative meetings. 
3.01 29. There is wide involvement of administrators in the development of their school's building budget.

2.84 30. Administrators have an opportunity to make appropriate input to promotion decisions concerning school district employees.

3.32 31. Administrators have an opportunity to make appropriate input to dismissal decisions concerning school district employees.

$\underline{2.83}$ 32. Administrators have input to administrative job descriptions. 
APPENDIX C

ADDITIONAL STATISTICAL INFORMATION 
ANALYSIS OF VARIANCE FOR BARGAINING AND NON-BARGAINING PRINCIPAL'S PERCEPTION REGARDING THE NINE

\section{PRIMARY HYPOTHESES.}

\begin{tabular}{lccccc}
\hline $\begin{array}{l}\text { Work } \\
\text { Conditions }\end{array}$ & $\begin{array}{c}\text { Mult. } \\
\mathbf{R}\end{array}$ & $\begin{array}{c}\text { Sq. } \\
\text { Mult. } \\
\mathbf{R}\end{array}$ & $\begin{array}{c}\text { Signf. } \\
\mathbf{p}=<.05\end{array}$ & $\begin{array}{c}\text { Sum } \\
\text { of } \\
\text { Sq. }\end{array}$ & $\begin{array}{c}\text { Mean } \\
\text { Sq. }\end{array}$ \\
\hline Salary & .014 & .000 & 0.869 & & \\
Formal Contracts & .205 & .042 & 0.015 & 2.165 & 2.165 \\
Antonomy & .232 & .054 & 0.006 & 4.163 & 4.163 \\
Power/Authority & .053 & .003 & 0.545 & & \\
Job Security & .036 & .001 & 0.681 & & \\
Fringe Benefits & .036 & .001 & 0.671 & & \\
Role Definition & .026 & .001 & 0.748 & & \\
Communication & .035 & .001 & 0.688 & & \\
Decision Making & .118 & .014 & 0.162 & & \\
\hline
\end{tabular}


ANALYSIS OF VARIANCE FOR PRINCIPAL'S LEVEL OF BARGAINING AND THE NINE SECONDARY HYPOTHESES.

\begin{tabular}{|c|c|c|c|c|c|}
\hline $\begin{array}{l}\text { Work } \\
\text { Conditions }\end{array}$ & $\underset{R}{\operatorname{Mult}}$ & $\begin{array}{l}\text { Sq. } \\
\text { Mult. } \\
\text { R }\end{array}$ & $\begin{array}{l}\text { Sum } \\
\text { of } \\
\text { sq. }\end{array}$ & $\begin{array}{l}\text { Mean } \\
\text { Sq. }\end{array}$ & $\begin{array}{l}\text { Signf. } \\
p=<.05\end{array}$ \\
\hline Salary & .380 & .144 & 11.267 & 5.634 & 0.000 \\
\hline Formal contracts & .028 & .001 & & & 0.950 \\
\hline Antonomy & .186 & .035 & & & 0.104 \\
\hline Power/Authority & .248 & .061 & 3.542 & 1.771 & 0.022 \\
\hline Job security & .264 & .070 & 4.131 & 2.066 & 0.013 \\
\hline Fringe Benefits & .247 & .061 & 11.687 & 5.843 & 0.016 \\
\hline Role Definition & .230 & .053 & 3.833 & 1.917 & 0.030 \\
\hline Communication & .073 & .005 & & & 0.715 \\
\hline Decision Making & .293 & .086 & 4.460 & 2.230 & 0.003 \\
\hline
\end{tabular}


ANALYSIS OF VARIANCE FOR DISTRICT CLASSIFICATION AND SIGNIFICANT WORKING CONDITIONS.

\begin{tabular}{|c|c|c|c|c|c|}
\hline & $\underset{R}{\operatorname{Mult}}$ & $\begin{array}{l}\text { Sq. } \\
\text { Muit. } \\
R\end{array}$ & $\begin{array}{l}\text { Sum } \\
\text { of } \\
\text { Sq. }\end{array}$ & $\begin{array}{l}\text { Mean } \\
\text { Sq. }\end{array}$ & $\begin{array}{l}\text { Signf. } \\
p=<.05\end{array}$ \\
\hline \multicolumn{6}{|c|}{$\begin{array}{l}\text { Primary Analysis } \\
\text { Bargain/Non-Bargain }\end{array}$} \\
\hline Autonomy & .253 & .064 & 4.978 & 1.659 & 0.027 \\
\hline Formal contracts & .278 & .077 & 3.985 & 1.328 & 0.011 \\
\hline \multicolumn{6}{|c|}{$\begin{array}{l}\text { Secondary Analysis } \\
\text { Level of Bargaining }\end{array}$} \\
\hline Salary & .388 & .150 & 12.805 & 4.268 & .000 \\
\hline Role Definition & .436 & .190 & 16.187 & 5.396 & .000 \\
\hline Decision Making & .253 & .064 & 3.631 & 1.210 & .028 \\
\hline
\end{tabular}


ANALYSIS OF VARIANCE FOR DISTRICT SIZE AND SIGNIFICANT WORKING CONDITIONS.

\begin{tabular}{|c|c|c|c|c|c|}
\hline & $\begin{array}{l}\mathrm{Mult} \\
\mathrm{R}\end{array}$ & $\begin{array}{l}\text { Sq. } \\
\text { Mult. } \\
\quad \text { R }\end{array}$ & $\begin{array}{l}\text { Sum } \\
\text { of } \\
\text { Sq. }\end{array}$ & $\begin{array}{l}\text { Mean } \\
\text { Sq. }\end{array}$ & $\begin{array}{l}\text { Signf. } \\
p=<.05\end{array}$ \\
\hline \multicolumn{6}{|c|}{$\begin{array}{l}\text { Primary Analysis } \\
\text { Bargain/Non-Bargain }\end{array}$} \\
\hline Formal Contracts & .228 & .052 & 2.680 & 1.340 & 0.025 \\
\hline \multicolumn{6}{|c|}{$\begin{array}{l}\text { Secondary Analysis } \\
\text { Level of Bargaining }\end{array}$} \\
\hline Salary & .363 & .132 & 11.230 & 5.615 & 0.000 \\
\hline Power/Authority & .209 & .044 & 2.816 & 1.409 & 0.055 \\
\hline Role Definition & .392 & .153 & 12.985 & 6.493 & 0.000 \\
\hline
\end{tabular}


ANALYSIS OF COVARIANCE: EFFECT OF DISTRICT CLASSIFICATION AND DISTRICT SIZE ON THE SIGNIFICANT WORKING CONDITION AREAS.

\begin{tabular}{lccccc}
\hline & $\begin{array}{c}\text { Mult. } \\
\mathrm{R}\end{array}$ & $\begin{array}{c}\text { Sq. } \\
\text { Mult. } \\
\mathrm{R}\end{array}$ & $\begin{array}{c}\text { Sum } \\
\text { of } \\
\text { Sq. }\end{array}$ & $\begin{array}{l}\text { Mean } \\
\text { Sq. }\end{array}$ & $\begin{array}{c}\text { Signf. } \\
\mathrm{p}=<.05\end{array}$ \\
\hline $\begin{array}{l}\text { Primary Analysis } \\
\text { Bargain/Non-Bargain }\end{array}$ & & & & & \\
\hline Autonomy & .318 & .101 & 3.284 & 3.284 & 0.012 \\
\hline Secondary Analysis & & & & & \\
Level of Bargaining & & & & & \\
\hline Salary & .490 & .240 & 7.313 & 3.656 & 0.001 \\
Decision Making & .345 & .119 & 4.111 & 2.205 & 0.003 \\
\hline
\end{tabular}

